\title{
Discovery of (4-bromophenyl)(3-hydroxy-4-methoxyphenyl) methanone through upregulating hTERT induces cell apoptosis and ERS
}

\author{
Xiu Cheng ${ }^{1,2,3}$, Jing Bo Shi ${ }^{1,3}$, Hao Liü ${ }^{2}$, Liu Zeng Chen ${ }^{1}$, Yang Wang ${ }^{1}$, Wen Jian Tang ${ }^{\star, 1}$ and Xin Hua Liu ${ }^{\star, 1}$
}

Dominant-negative mutants of telomerase hTERT were demonstrated to have selective effects in tumor cells. However, no any effective and highly selective hTERT inhibitor has been developed so far. We focused on developing new hTERT modulators and synthesized a small molecular compound, named (4-bromophenyl)(3-hydroxy-4-methoxyphenyl)methanone. Our in vitro studies found that title compound showed high inhibitory activity against telomerase, had high antiproliferative capacity on SMMC-7721 cells with $\mathrm{IC}_{50}$ value $88 \mathrm{~nm}$, and had no obvious toxic effect on human normal hepatocyte cells with $\mathrm{IC}_{50}$ value $10 \mu \mathrm{M}$. Our in vivo studies showed that this compound significantly inhibited tumor growth in xenograft tumor models. The further molecular mechanisms of title compound inhibition SMMC-7721 cell proliferation by modulating hTERT were explored; the results showed that endoplasmic reticulum stress (ERS) through ER over response (EOR) activates the expression of hTERT, and then induces ERS, which is believed to be intricately associated with oxidative stress and mitochondrial dysfunction, resulting in apoptotic cell death, thereby modulating the expression of downstream signaling molecules including CHOP (CAAT/enhancer-binding protein homologous protein)) and mitochondrion pathway of apoptosis, leading to inhibition of cell proliferation.

Cell Death and Disease (2017) 8, e3016; doi:10.1038/cddis.2017.384; published online 24 August 2017

Telomerase has an important role in chromosomal integrity of frequently dividing cells. ${ }^{1-5}$ One of the pivotal tumor escape mechanisms is the activation of telomerase to surround the telomere-based cell death signaling pathways. ${ }^{6,7}$ As the component of telomerase, telomerase reverse transcriptase (hTERT) has been identified as a major protein involved in various cancer cell proliferation and apoptosis, although it has little or no expression in normal somatic cells. ${ }^{8}$ Therefore, this differential expression and the multiple crucial roles make it a highly attractive target in the diagnosis of cancer, as well as in providing guidance for novel drug design. During past decades, much evidence suggested that the regulatory effect of hTERT could be used to obtain in-depth insight into tumors in the future. ${ }^{9,10} \mathrm{~A}$ lot of work has been carried out in the field of targeted telomerase hTERT. ${ }^{11,12}$ Some hTERT inhibitors with good anticancer activity, including BIBR1532, ${ }^{13-15}$ anthraquinone,${ }^{16}$ and TMPI, ${ }^{17}$ have been found. Although most of the reported $\mathrm{hTERT}$ inhibitors also exhibited potential toxicity against somatic cell, no inhibitors targeting hTERT were approved by FDA so far. Therefore, focused on hTERT, design of potent low-toxicity modulators with novel molecular mechanism by regulating hTERT expression is one of the strategies.

Recently, a novel dihydropyrazole-chromen with selectivity against tumor cells versus normal human cells was discovered; ${ }^{11}$ the inhibition mechanisms showed that expression of hTERT was clearly downregulated, resulting in the expression of downstream signaling molecules including c-myc. This preliminarily shows that it becomes possible by controlling the
hTERT to inhibit tumor. In our preliminary research based on telomerase, ${ }^{18}$ a series of phenstatin-stavudine hybrids were designed, in which some compounds displayed potent antitelomerase activity with inhibition of tumor growth of S180. In continuation of our research into potent telomerase hTERT regulators, some new phenstatin derivatives were optimized. Among them, one compound showed very high antitumor activity and selectivity to normal cells. What is more surprising is that hTERT was upregulated as early as $3 \mathrm{~h}$ and decreased at $12 \mathrm{~h}$ post induction. In order to indicate the direction for design of new compounds, the regulatory mechanisms of hTERT expression were preliminarily revealed in this study.

\section{Results}

Synthesis and characterization. The title compound was synthesized according to the previous report ${ }^{18}$ (Supplementary Figure 1). The structure (Figure 1) was characterized by ESI-MS, ${ }^{1} \mathrm{H}$ NMR, and elemental analyses.

Cell viability. The effect of the title compound on the viability of human hepatoma cancer cell (SMMC-7721) was examined by increasing concentrations (3.2, 16, 80, 400, and $2000 \mathrm{~nm})$. A normal liver cell line (L-02) was used as control. Cell viability was measured by MTT assay at $48 \mathrm{~h}$. Title compound treatment decreased the growth of cancer cells in dose- and

\footnotetext{
${ }^{1}$ Anhui Province Key Laboratory of Major Autoimmune Diseases, Anhui Institute of Innovative Drugs, School of Pharmacy, Anhui Medical University, Hefei 230032, PR China and ${ }^{2}$ School of Pharmacy, BengBu Medical College, BengBu 233030, PR China

${ }^{*}$ Corresponding author: WJ Tang or XH Liu, Anhui Province Key Laboratory of Major Autoimmune Diseases, Anhui Institute of Innovative Drugs, School of Pharmacy, Anhui Medical University, Anhui, Hefei 230032, PR China. Tel/Fax: +86 551651611 15; E-mail: ahmupharm@ 126.com or xhliuhx@163.com

${ }^{3}$ These authors contributed equally to this work.

Received 29.3.17; revised 05.7.17; accepted 06.7.17; Edited by B Zhivotovsky
} 
time-dependent manners (Figure 2a); however, the viability of L-02 showed slight changes in the compound at $10 \mu \mathrm{M}$. These results indicated that the title compound could inhibit growth of cancer cells but had little effect on normal cells. Similarly, as shown in Figure $2 b$, the title compound could inhibit the growth of SMMC-7721 and promote the formation<smiles>COc1ccc(C(=O)c2ccc(Br)cc2)cc1O</smiles>

Figure 1 Structure of title compound

a

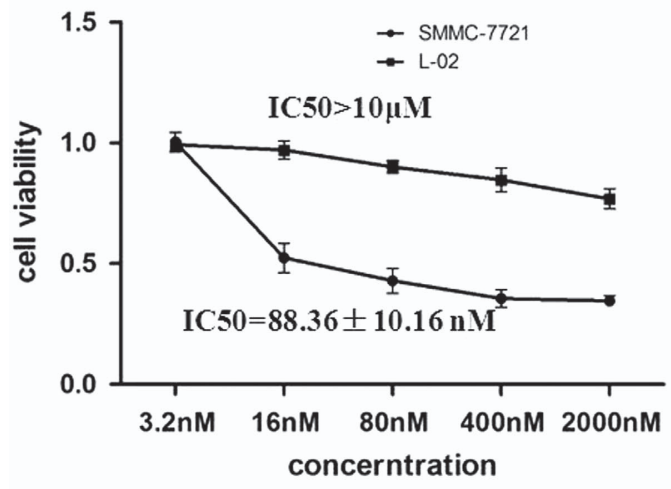

C

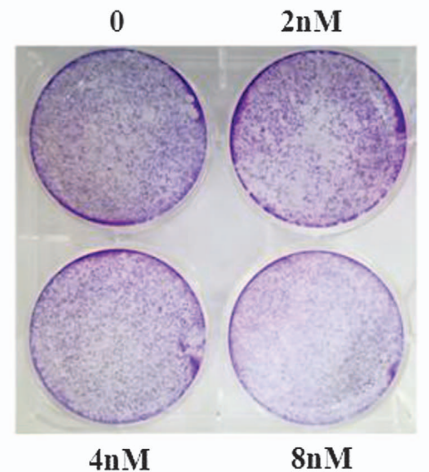

of rounded floating cells. Colony formation assays were also used to confirm that the low concentration of the title compound inhibited the growth of cells (Figure $2 \mathrm{c}$ ).

Cell apoptosis. To investigate the effect of the title compound on SMMC-7721 cell apoptosis, Annexin V/propidium iodide (PI) was used to assess. As shown in Figures $3 a$ and $\mathrm{b}, 48 \mathrm{~h}$ of SMMC-7721 cell treatment with the title compound $(20,40$, and $80 \mathrm{~nm})$ caused increase of apoptosis. JC-1 was used to assess the mitochondrial membrane potential (MMP) of SMMC-7721 cells. Forty-eight hours of SMMC-7721 cell treatment with the title compound (20,40, and $80 \mathrm{~nm})$ caused significant accumulation of green fluorescence, indicating a decrease in MMP (Figures $3 \mathrm{c}$ and d). SMMC-7721 cells were treated with the title compound for $0,3,6,12,24$, and $48 \mathrm{~h}$,
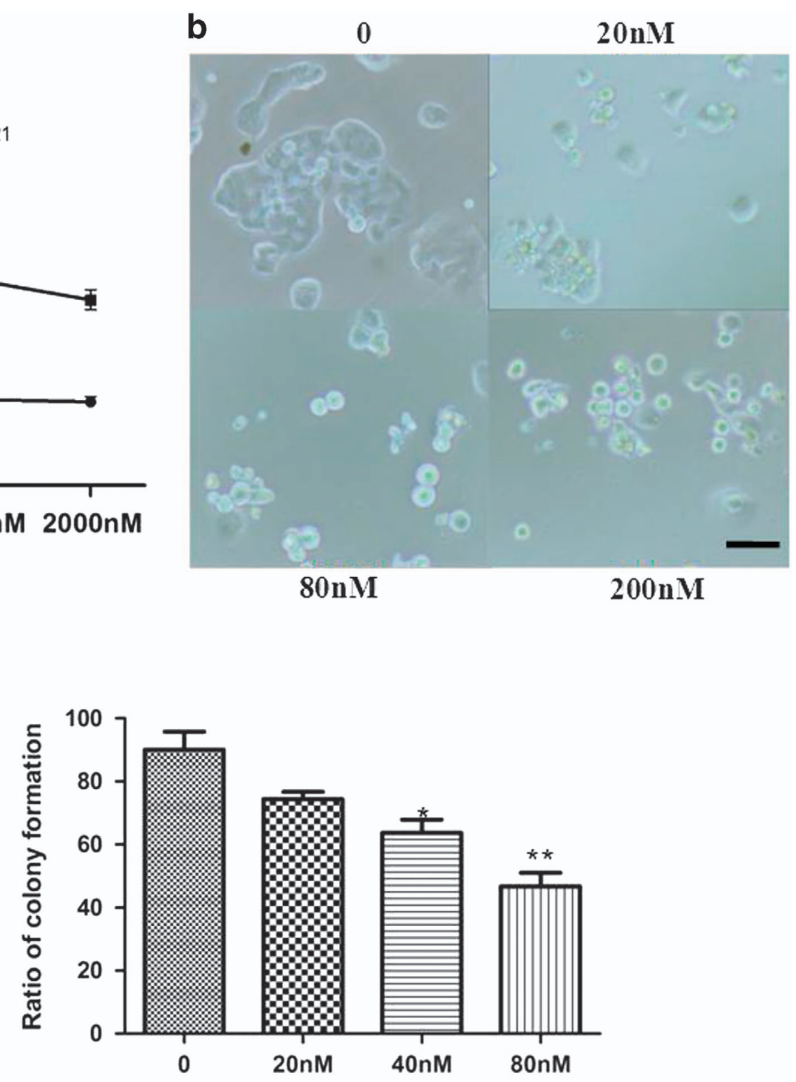

Figure 2 Cell viability. (a) Cell viability after $48 \mathrm{~h}$ treatment of SMMC-7721 and L-02 cells with different concentrations of the title compound as estimated by MTT. (b) Morphology of SMMC-7721 cells viewed using inverted phase-contrast microscope (magnification $\times 200$ ). SMMC-7721 cells treated with title compound (20,40, and 200 nM) for $48 \mathrm{~h}$. (c) SMMC-7721 cells were treated with control (no treatment), 2, 4, and $8 \mathrm{nM}$ for 7 days. For the statistics of each panel in this figure, data are expressed as mean \pm S.D. $(n=3)$. Scale bars are $50 \mu \mathrm{m} .{ }^{*} P<0.05$ versus control and ${ }^{*} P<0.01$ versus control

Figure 3 Compound induced cell apoptosis. (a) SMMC-7721 cells treated with the title compound (20,40, and $80 \mathrm{~nm}$ ) for $48 \mathrm{~h}$ were stained with Annexin V/PI and then were analyzed using fluorescence cytometry and (b) fluorescence microscopy (magnification $\times 200$ ). (c) Mitochondrial membrane depolarization analysis was performed by detecting the mitochondrial transmembrane potential using JC-1 stain treated with the compound for $48 \mathrm{~h}$ and then it was analyzed with fluorescence cytometry and (d) fluorescence microscopy (magnification $\times 200$ ). (e) Western blot and densitometric analyses for Bcl-2/Bax and cyt-c after SMMC-7721 cells treated with the title compound. (f) Compound induced nuclear chromatin condensation. SMMC- 7721 cells were treated with $0,20,40$, and $80 \mathrm{~nm}$ of the title compound for $48 \mathrm{~h}$ and then were stained with DAPI as described in Materials and Methods. Cells were examined and photographed using a fluorescence microscope at $\times 200$. Representative blots were from three independent experiments. For the statistics of each panel in this figure, data are expressed as mean \pm S.D. $(n=3)$; scale bars are $50 \mu \mathrm{m} ;{ }^{*} P<0.05$ versus control, ${ }^{*} P<0.01$ versus control, ${ }^{* * \star} P<0.001$ versus control 

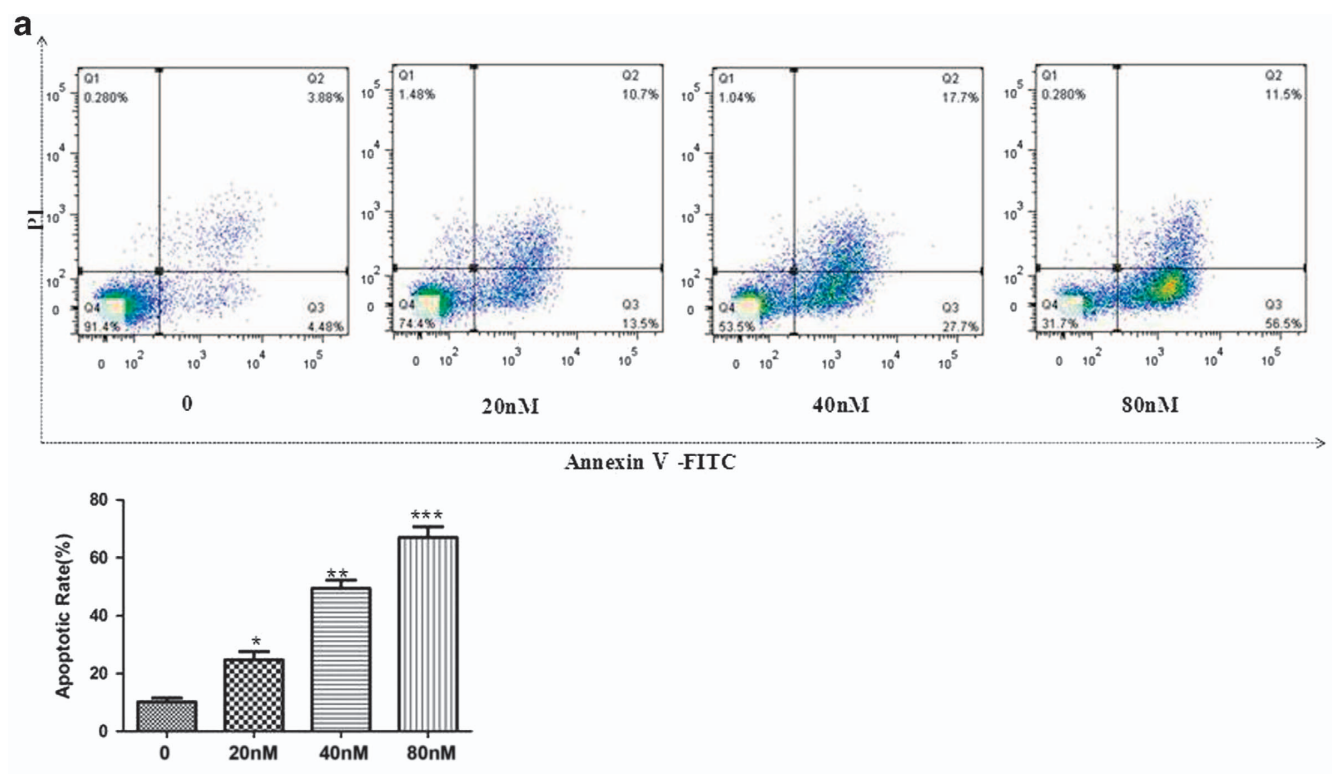

b
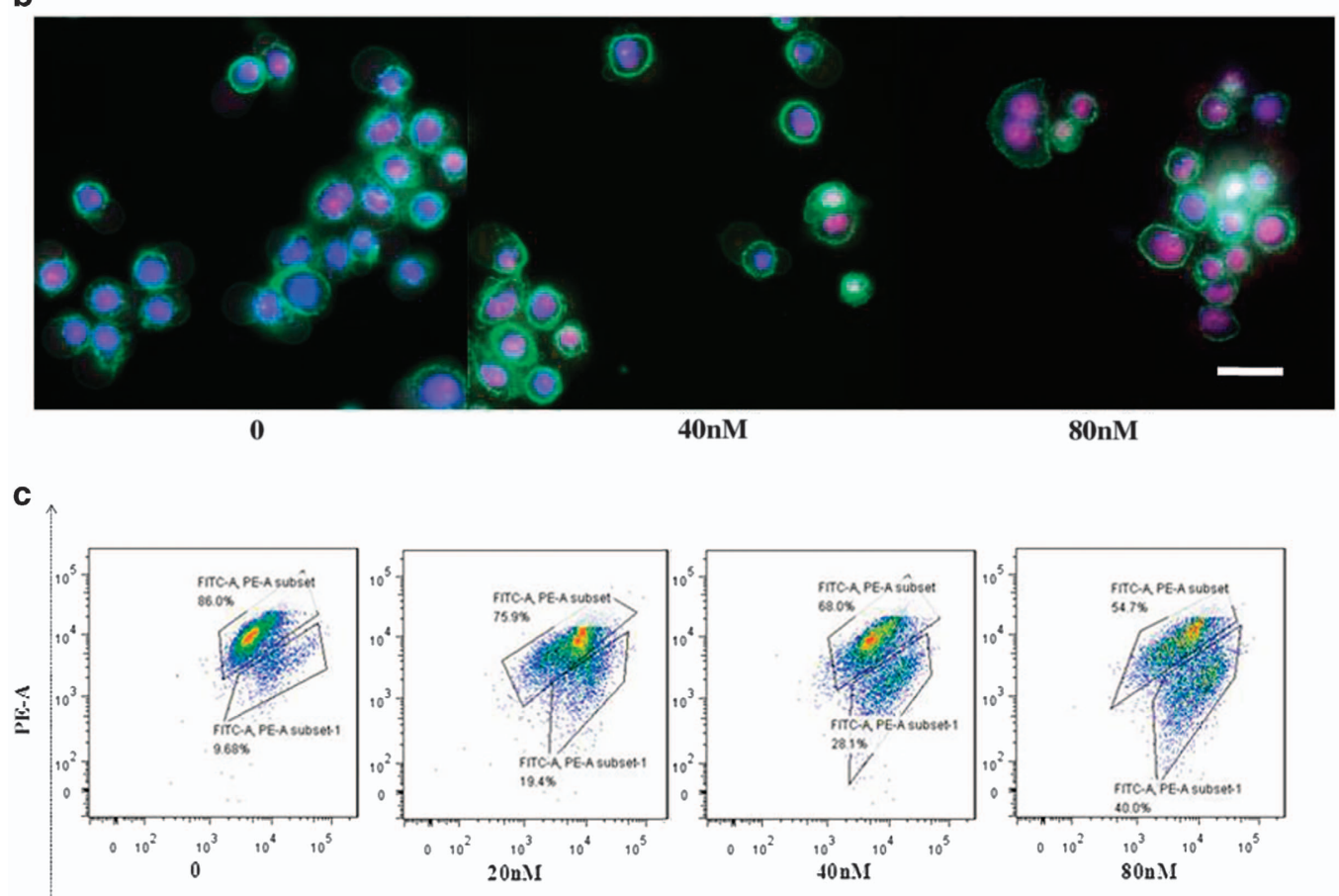

FITC-A

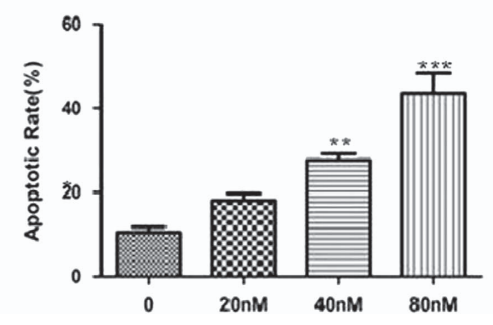


and the protein levels of cyt-c and Bcl-2/Bax were monitored. At $40 \mathrm{~nm}$, the title compound significantly increased expressions of cyt-c and Bax, but the Bcl-2 level was decreased
(Figure 3e). Treated with title compound (20, 40, and $80 \mathrm{~nm}$ ) for $48 \mathrm{~h}$ and then stained with DAPI, photographed by fluorescence microscopy and the results indicated that title

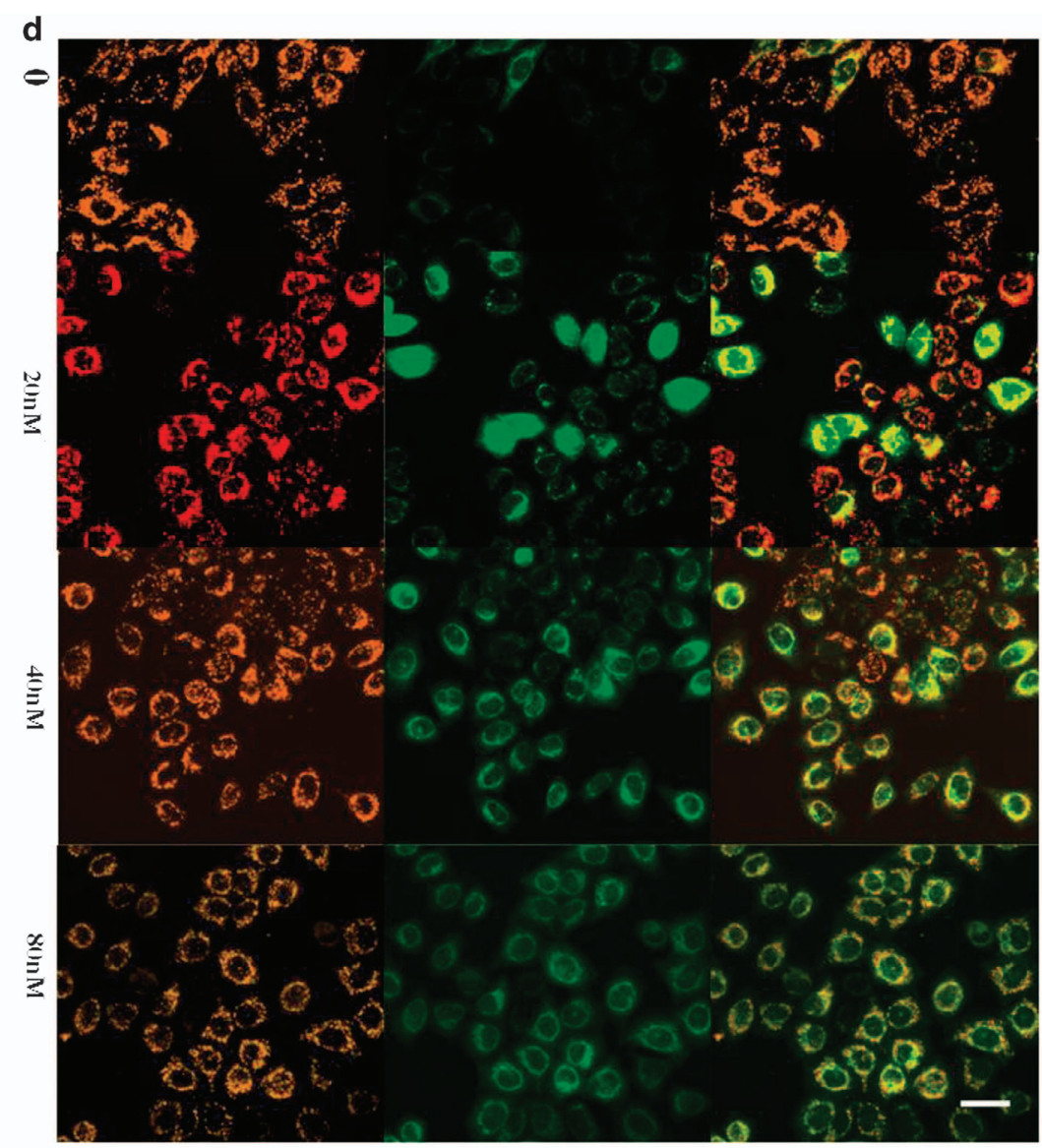

e

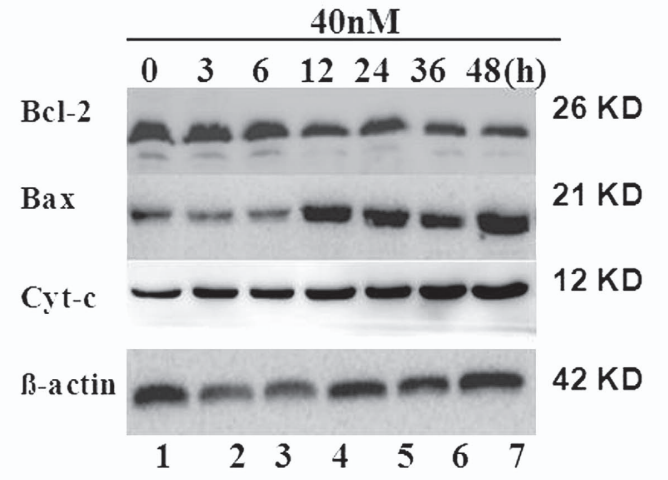

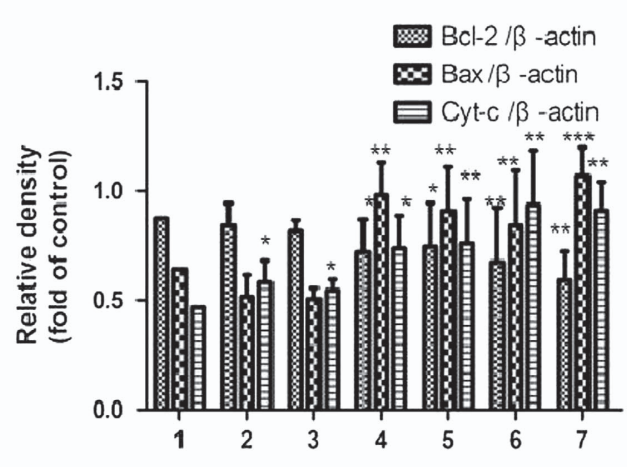

f

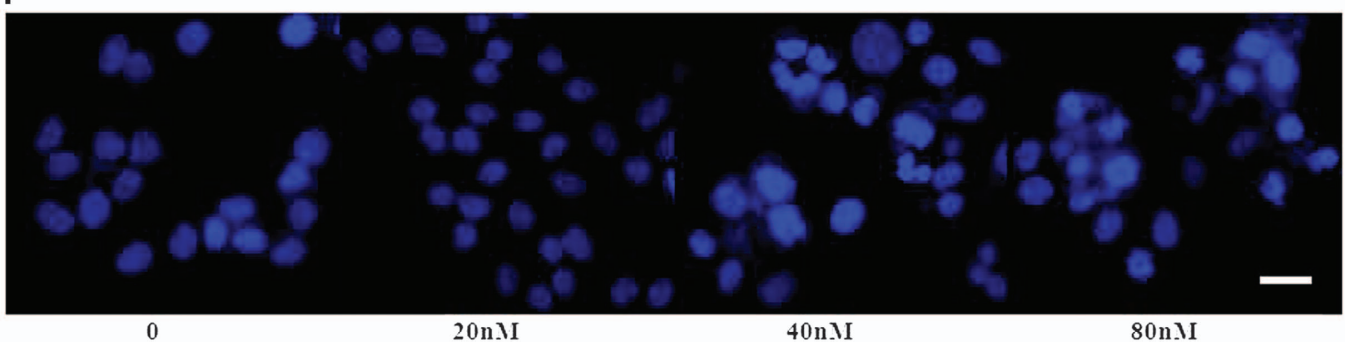

Figure 3 Continued 
compound (with high concentration) led to brighter DAPI fluorescence of SMMC-7721 cells compared to control (Figure 3f), which means that cells have nicked DNA and nuclear chromatin was condensed.

In a word, as shown in the DAPI assay, the title compound induces typical DNA fragmentation in SMMC-7721 cells. Meanwhile, the results of flow cytometry analysis indicated that the percentage of apoptotic cells evidently increased as the title compound concentrations change. Besides, chromosomal DNA fragmentation, including changed morphology with condensed and fragmented nuclei, were observed in the SMMC-7721 cells. In addition, western blot and densitometric analyses showed that cytochrome-c (cyt-c) was increased when treated with the title compound. Thus, the reduction of MMP and the release of cyt-c preliminarily showed that the title compound induces apoptosis of SMMC-7721 cells potentially via the apoptotic pathway.

Telomerase activity. To confirm whether the title compound performed anticancer activity via telomerase inhibition as designed, the title compound was evaluated by a modified TRAP assay using an extraction from SMMC-7721 cells. The results indicated that the title compound showed potent inhibitory activity against telomerase with $\mathrm{IC}_{50}$ value at $0.19 \mu \mathrm{M}$, better than positive control BIBR1532 (Supplementary Table 1).

Downregulation of the expression of hTERT. As the component of human telomerase, hTERT has been identified as a major protein involved in aberrant cell apoptosis in various cancers. In this study, to investigate the title compound on the expression of hTERT, western blot and densitometric analyses were used to assess the expression of hTERT. As shown in Figure 4a, SMMC-7721 cells treatment with the title compound $(20,40$, and $80 \mathrm{~nm}$ for $24 \mathrm{~h}$ ) caused a decrease in hTERT. Quantitative reverse transcription PCR (qRT-PCR) was also used to assess the mRNA of hTERT. As shown in Figure $4 \mathrm{~b}$, the title compound $(20,40$, and $80 \mathrm{~nm})$ could decrease hTERT mRNA.

To explore the mechanisms why the title compound could change the expression of hTERT. We then investigated the effect of the title compound on the expression of p65, and western blot and densitometric analyses were used to assess the expression of p65. Twenty-four hours of SMMC-7721 cell treatment with the title compound $(20,40$, and $80 \mathrm{~nm})$ decreased p65. The expressions of hTERT and p65 were further confirmed with immunofluorescence. As shown in Figure $4 \mathrm{c}, 24 \mathrm{~h}$ of SMMC-7721 cell treatment with the title compound (20, 40, and $80 \mathrm{~nm})$ decreased fluorescence intensity for hTERT (green), p65 (red), and DAPI (blue). SMMC-7721 cells were treated with the title compound for 0,3 , $6,12,24$, and $48 \mathrm{~h}$ in $40 \mathrm{~nm}$, and the protein levels of hTERT, p65, and $I_{\kappa} \mathrm{B} a$ were monitored. As shown in Figure $4 \mathrm{~d}, \mathrm{I}_{\kappa} \mathrm{B} a$, hTERT, and p65 were upregulated as early as $3 \mathrm{~h}$ and decreased at $12 \mathrm{~h}$ post induction.

Induction of ERS. In our previous studies, we found that small molecules usually downregulated the expression of hTERT to inhibit the activity of telomerase, resulting in induced cancer cell apoptosis. Why is the expression of
$\mathrm{hTERT}$ and $\mathrm{p} 65$ upregulated as early as $3 \mathrm{~h}$ and decreased at $12 \mathrm{~h}$ post induction in this study? Focused on this somewhat surprising result, in order to develop novel hits by targeting hTERT in the future, the preliminary mechanisms for this were tried to reveal.

It was discovered that endoplasmic reticulum stress (ERS) transiently activates telomerase hTERT expression in human cancer cell lines and murine primary neural cells. ${ }^{19}$ Two ER responses have been described to arise from the overaccumulation of proteins: unfolded protein response (UPR) and ER over response (EOR). UPR and EOR employ various mechanisms at the transcriptional and the translational levels to deal efficiently and appropriately with encountered stress. ${ }^{20}$ To investigate the effect of the title compound that increased the expression of hTERT as early as $3 \mathrm{~h}$ and decreased at $12 \mathrm{~h}$ post induction, the expression of GRP-78, which serves as a gate keeper to the activation of ERS transducers was examined. The results indicated that treatment with the title compound significantly increased the expression of GRP-78/ Bip. As shown in Figure 5a, 24 h of SMMC-7721 cell treatment with the title compound (20, 40, and $80 \mathrm{~nm})$ increased GRP-78 as seen by western blot and densitometric analyses. qRT-PCR was also used to assess the mRNA of GRP-78. As shown in Figure $5 \mathrm{~b}, 24 \mathrm{~h}$ of SMMC-7721 cell treatment with the title compound (20, 40, and $80 \mathrm{~nm}$ ) increased GRP-78 mRNA. The expression of GRP-78 was further confirmed using immunofluorescence. The title compound (20, 40, and $80 \mathrm{~nm}$ ) increased fluorescence intensity for GRP-78 (red) and DAPI (blue).

UPR and EOR show distinct mediators in the signaling pathway and target different genes to generate responses. EOR activates inhibitor of $\kappa \mathrm{B}$ kinase, which causes degradation of the inhibitor of $\kappa \mathrm{B}(\mathrm{I}-\kappa \mathrm{B})$. This allows for the activation of nuclear factor $-\kappa \mathrm{B}(\mathrm{NF}-\kappa \mathrm{B})$, a transcription factor that induces the expression of genes encoding several proteins involved in death/survival decisions and inflammatory responses. ${ }^{20}$ At the same time, it was well known that the transcription factor NF$\kappa \mathrm{B}$ has been implicated with the regulation of hTERT transcription. We then investigated whether NF-kB was involved in up- and downregulation of hTERT expression under ERS. Therefore, we investigated the effect of the title compound on the expression of p65; western blot analysis was used to assess the expression of p65. Twenty-four hours of SMMC-7721 cell treatment with the compound $(20,40$, and $80 \mathrm{~nm}$ ) decreased p65. SMMC-7721 cells were treated with the compound for $0,3,6,12,24$, and $48 \mathrm{~h}$ in $40 \mathrm{~nm}$, and the protein levels of hTERT, p65, I $\mathrm{B} a$, and GRP-78 were monitored (Figure $5 \mathrm{c}$ ). The expression of hTERT was upregulated as early as $3 \mathrm{~h}$ after ERS induction and decreased at $12 \mathrm{~h}$ post induction; we therefore conclude that the anti-apoptosis effect of increased hTERT expression under ERS may be independent of telomere maintenance. The results establish a functional link between ERS and telomerase, both of which have important implications in the pathologies associated with cancer.

In general, growth factors and cytokines regulate hTERT in non-immortalized primary somatic cells. However, recent data indicate that the hTERT expression can be regulated in somatic cells. ${ }^{21}$ Whereas it is not certain what the role of $N F-\kappa B$ regulation of $h T E R T$ is in normal cell function. hTERT 
a

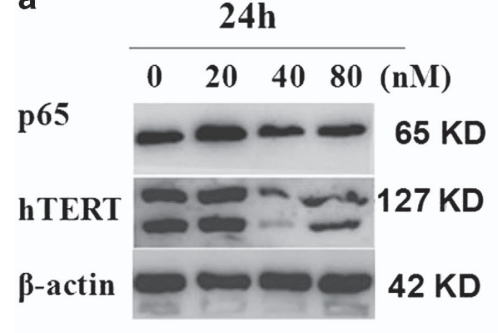

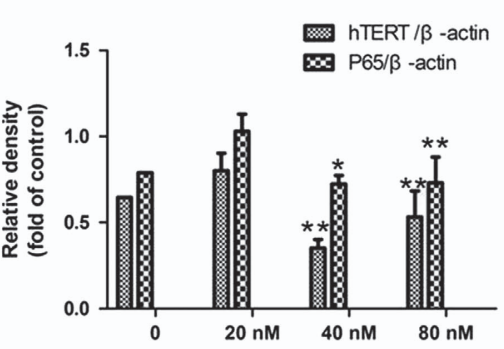

b

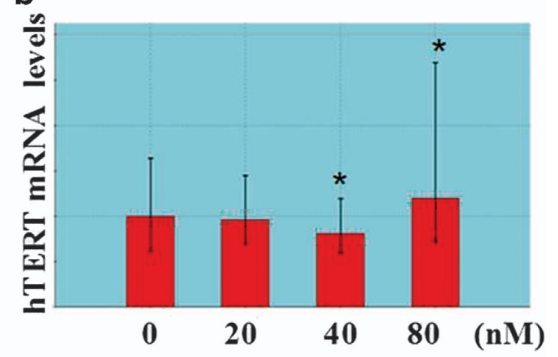

c

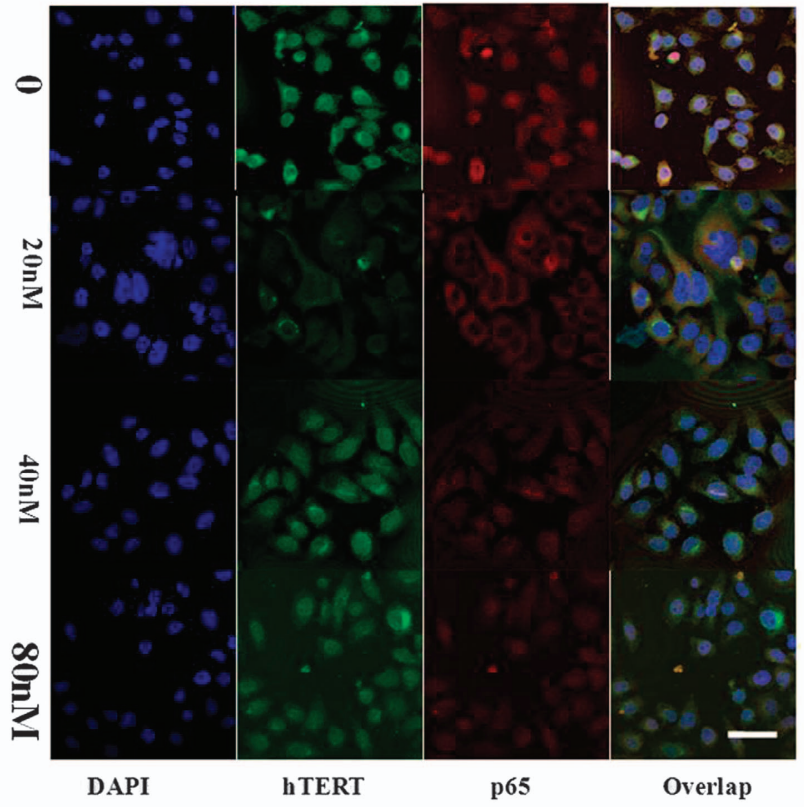

d
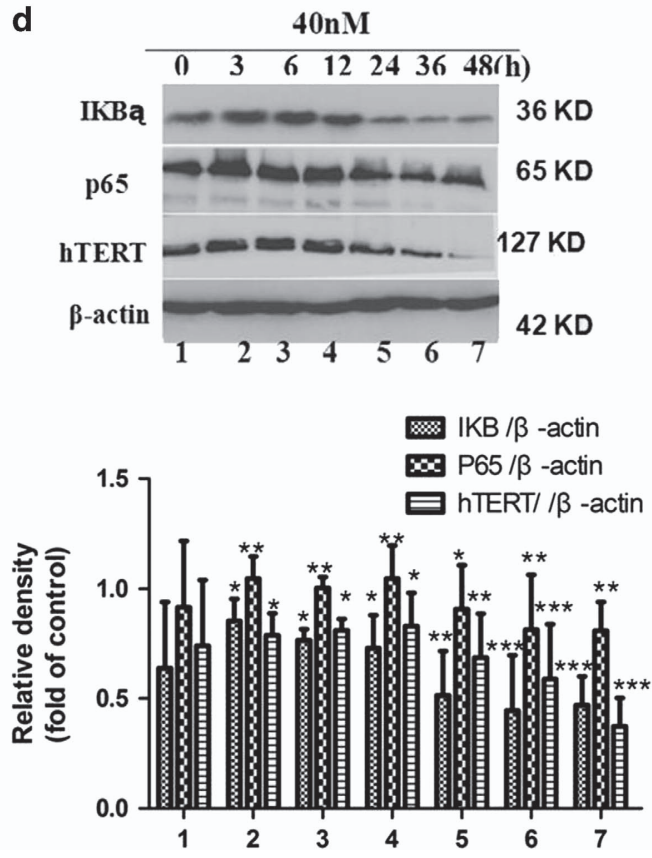

Figure 4 Decreased expression of hTERT. (a) Western blot and densitometric analyses for hTERT and p65 treated with the title compound (20, 40, and $80 \mathrm{nm)} \mathrm{for} 24 \mathrm{~h}$. $\beta$-actin was used as the internal control. (b) At the indicated time points, cells were harvested for qRT-PCR analysis of hTERT mRNA expression. $\beta$-actin was used as the internal control. (c) Immunofluorescence assay for the expression of hTERT and p65 after SMMC-7721 cells treated with the title compound (20, 40, and $80 \mathrm{nm)} \mathrm{for} 24 \mathrm{~h}$ and immunostained with anti-hTERT and anti-p65 antibodies. Fluorescence-labeled cells were analyzed under fluorescence microscope. Cells were examined and photographed using a fluorescence microscope at $\times 400$. (d) Western blot and densitometric analyses for hTERT-, p65-, and IKB-treated compounds (40 nм) for $0,3,6,12,24$, and $48 \mathrm{~h}$. $\beta$-actin was used as the internal control. For the statistics of each panel in this figure, data are expressed as mean \pm S.D. $(n=3)$; scale bars are $25 \mu \mathrm{m}$; ${ }^{*} P<0.05$ versus control, ${ }^{* \star} P<0.01$ versus control, ${ }^{* \star *} P<0.001$ versus control

was upregulated immediately upon ERS induction, suggesting transcriptional regulation. There are a number of clues from previous lines of work that ERS pathway triggers activation of the transcription factor $\mathrm{NF}-\mathrm{KB}^{22}$ and that the transcription factor NF- $\kappa B$ has been implicated with the regulation of hTERT transcription. ${ }^{23,24}$ Similarly, ERS-induced hTERT upregulation was compromised in the presence of the specific NF- $k B$ inhibitor PDTC. These results indicate that the NF- $k B$ pathway may be required for upregulation of hTERT under ERS. We then first investigated whether NF-kB was involved in upregulation of hTERT expression under ERS. We observed that ERS increased nuclear translocation of the NF-KB p65 transcription factor, which correlated with a concomitant decrease in the $1 \kappa \mathrm{B} a$ and an increase in the NF- $\kappa \mathrm{B}$ reporter activity. These results indicate that the NF- $k B$ pathway may be through EOR for upregulation of hTERT under ERS. When the ERS was too serious, the function of EOR was disabled and the expression of p65 and hTERT decreased. Then, the ERS apoptotic pathway was induced.

Activation of the expression of ERS-related apoptosis. Next, we focused on the ERS apoptotic pathway. First, we examined the effects of the compound on CHOP (CAAT/ enhancer-binding protein homologous protein), a hallmark of ERS, by western blot analysis. The results showed that treatment with the title compound for $3,6,12,24,36$, and $48 \mathrm{~h}$ $(40 \mathrm{~nm})$ significantly increased the expression of $\mathrm{CHOP}$ (Figure 6a). Then, we investigated the upstream and downstream signaling pathways of CHOP. The two principal UPR receptors involved are PERK and IRE1, all of which induce expression of CHOP. The protein levels of PERK-elF2 $\alpha$-ATF4 were examined with western blot analysis. The results showed that the title compound ( $40 \mathrm{~nm})$ could markedly increase the autophosphorylation of PERK and elF2a. In 
a

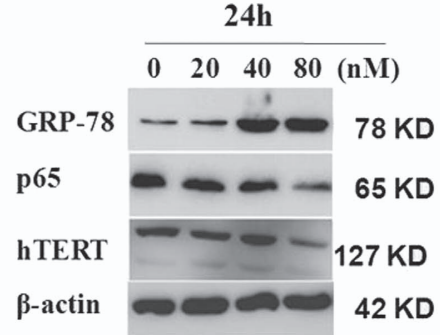

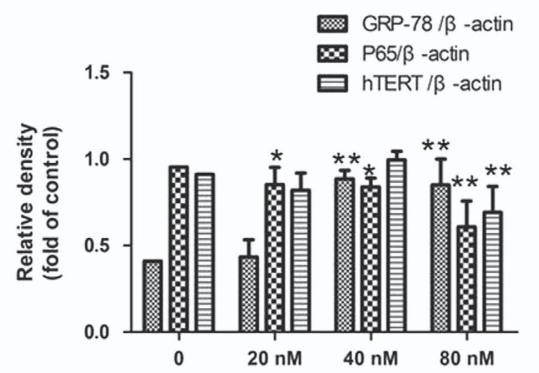

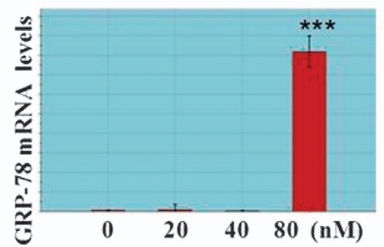

b

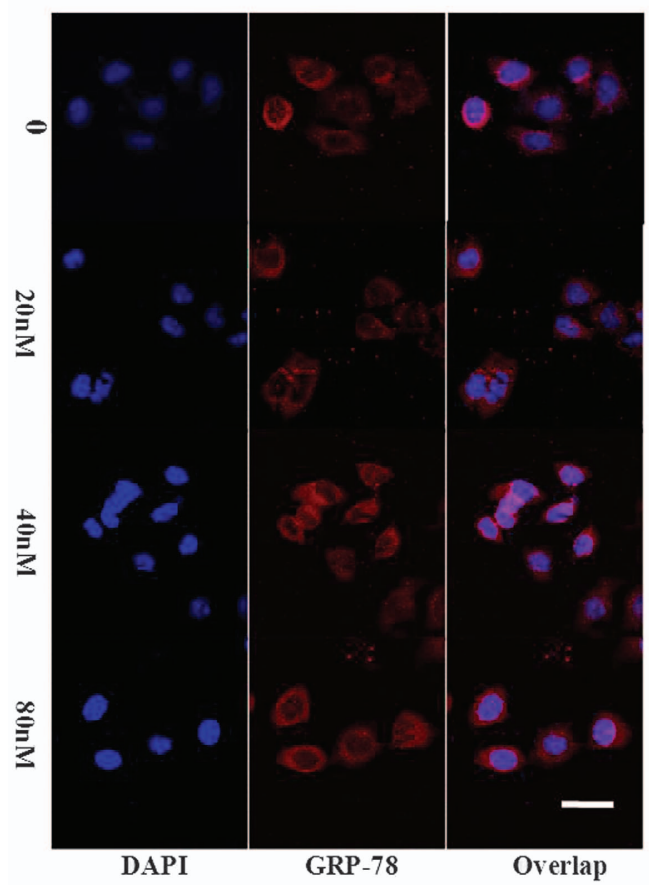

C
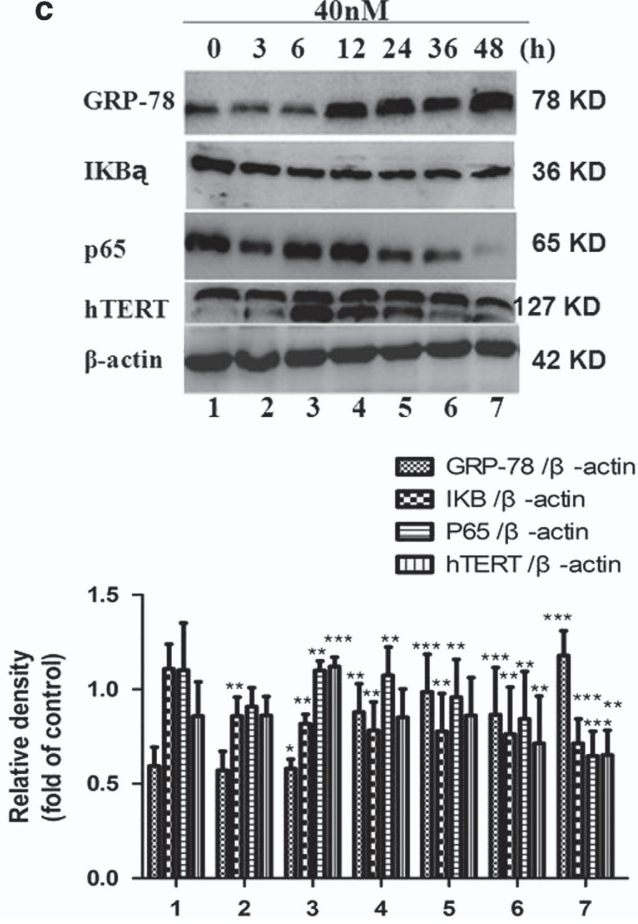

Figure 5 Induced ERS in SMMC-7721 cells. (a) Western blot and densitometric analyses for hTERT, p65, and GRP-78 after SMMC-7721 cells were treated with the title compound $(20,40$, and $80 \mathrm{~nm})$ for $24 \mathrm{~h}$. At the indicated time points, cells were harvested for qRT-PCR analysis of GRP-78 mRNA expression. $\beta$-actin was used as the internal control. (b) Immunofluorescence assay for the expression of GRP-78 after SMMC-7721 cells treated with the title compound (20, 40, and $80 \mathrm{nm)} \mathrm{for} 24 \mathrm{~h}$ and immunostained with anti-GRP-78 antibodies. Fluorescence-labeled cells were analyzed under a fluorescence microscope. (c) Western blot and densitometric analyses for $h T E R T, I_{k} B \alpha, p 65$, and GRP-78 treated with the title compound ( $40 \mathrm{~nm}$ ) for $0,3,6,12,24$, and $48 \mathrm{~h} . \beta$-actin was used as the internal control. For the statistics of each panel in this figure, data are expressed as mean \pm S.D. $(n=3)$; scale bars are $25 \mu \mathrm{m} ;{ }^{*} P<0.05$ versus control, ${ }^{\star \star} P<0.01$ versus control, ${ }^{* \star}{ }^{*} P<0.001$ versus control

addition, ATF4, the downstream target of elF2a, was increased as well. Some studies have demonstrated that the UPR could activate the mitochondrial apoptotic pathway through JNK/IRE1, which is critically regulated by several members of the Bcl-2 family. ERS induces conformational changes in Bax, changing them from inactive to active forms. ${ }^{25,26}$ We then examined the effects of the title compound on IRE1/p-IRE1a, Bcl-2/Bax, and caspase-3 by western blot and densitometric analyses. The results showed that $40 \mathrm{~nm}$ title compound treatment for 3, 6, 12, 24, 36, and $48 \mathrm{~h}$ significantly increased the expression of $\mathrm{p}$-IRE1a, Bax, and caspase-3 protein (Figure 6b).

Above results suggest that the $\mathrm{Bcl}-2$ family has a crucial role in regulating ERS-induced apoptosis; western blot analyses 
$40 \mathrm{nM}$
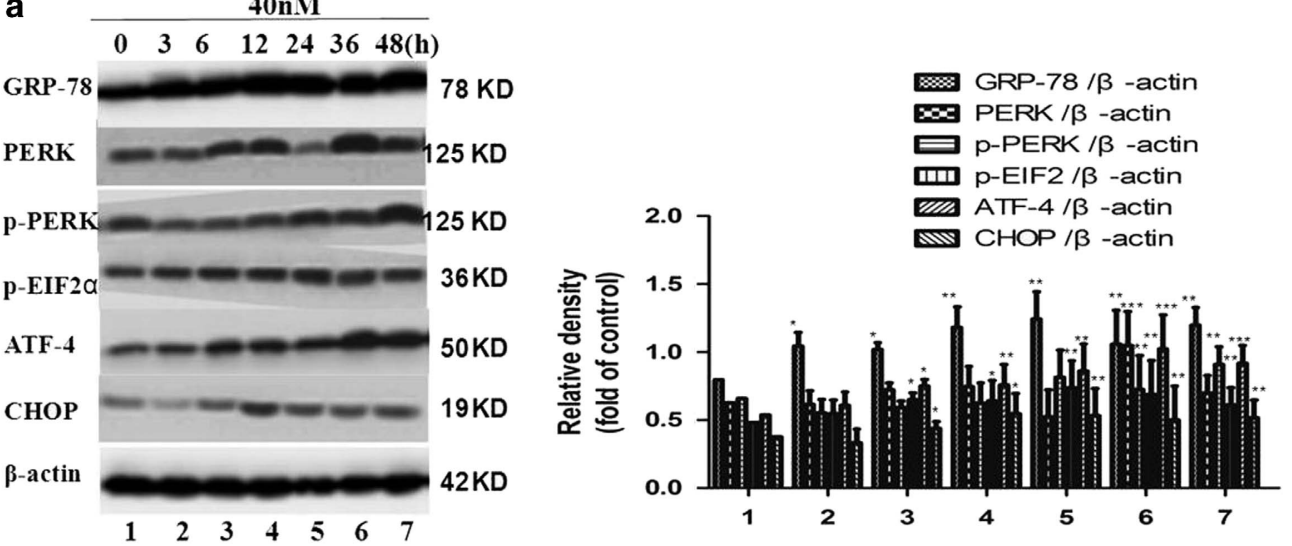

b
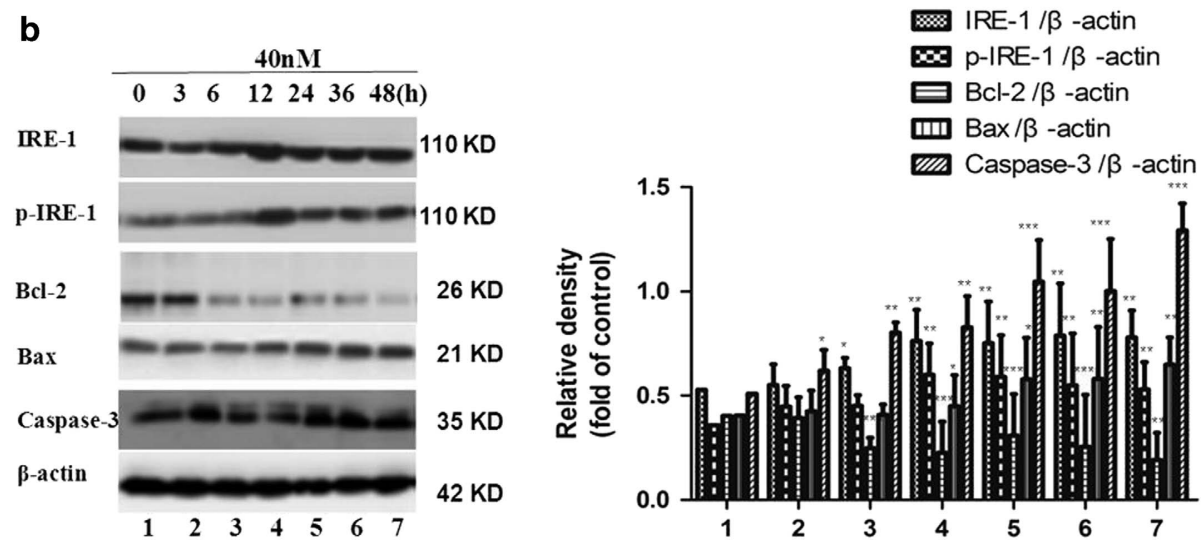

Figure 6 Effect on ER stress sensors in SMMC-7721 cells. (a) Total proteins were extracted from SMMC-7721 cells treated with the title compound for 0, 3, 6, 12, 24, 36, and $48 \mathrm{~h}$, and were subjected to western blot and densitometric analyses. The densitometric quantitation ratio of ER stress sensors (p-PERK/PERK, p-eIF2 $\alpha /$ elF2 $\alpha$, ATF4, and $\mathrm{CHOP}$ ) normalized to the $\beta$-actin level. (b) The effects of the title compound on IRE1/p-IRE $1 \alpha, \mathrm{Bcl}-2 / \mathrm{Bax}$, and caspase-3 by western blot and densitometric analyses. For the statistics of each panel in this figure, data are expressed as mean \pm S.D. $(n=3) ;{ }^{*} P<0.05$ versus control, ${ }^{* \star} P<0.01$ versus control, ${ }^{* \star *} P<0.001$ versus control

were used to assess the expressions of IRE1a, p-IRE1a, caspase-3, Bcl-2, and Bax. The other way, it can activate the PERK-elFa-ATF4-CHOP pathway to induce apoptosis. Western blot analyses were also used to assess the expressions of GRP-78, PERK/p-PERK, p-elF2 $a$, ATF4, and CHOP. Therefore, we further examined ERS-associated proteins in these cell lines. First, the phosphorylation patterns of PERK and elF2 $a$ were assessed, as PERK, an ER-resident transmembrane kinase, is known to autophosphorylate its cytoplasmic kinase domain in response to accumulated unfolded proteins in the ER lumen and activated PERK is subsequently capable of phosphorylating several cytosolic proteins including elF2 $a^{27,28}$ Western blot analysis revealed that treatment of cells with the title compound ( $40 \mathrm{~nm}$ ) led to an increase in the phosphorylation of PERK up to $48 \mathrm{~h}$ and elF2 $a$ for up to $48 \mathrm{~h}$ of treatment. The expression of GRP-78 was also examined. The results indicated that treatment with the title compound significantly increased the expressions of GRP-78/Bip and CHOP and led to activate the expression of ERS-related apoptosis.

Antitumor activity in vivo. To test whether the title compound shows any antitumor effect in vivo, SMMC-7721 cells were xenografted into nude mice, and then the tumor-bearing animals were treated with the title compound
(25, 50, and $100 \mu \mathrm{M} /$ daily) for 37 days by intraperitoneal injection. We observed that compound prevented tumor growth (Figure 7a) compared with the control. When each animal was considered individually, the incidence of mice progressing with a tumor volume of $500 \mathrm{~mm}^{3}$ was significantly diminished by 15 days with title compound-treated animals compared with controls (Figure $7 \mathrm{~b}$ ). Consistent with body weight data, title compound-treated groups exhibited obvious decrease in tumor weight (Figure 7c). Aspartate aminotransferase (AST) and alanine aminotransferase (ALT) are commonly used as biomarkers for the evaluation of hepatotoxicity, ${ }^{29}$ after treatment of the title compound, the levels of AST and ALT were analyzed using an activity assays, the results showed that title compound had nearly no effect on the AST and ALT compared with those of the control group (Figure 7d). H\&E staining of the organs such as the liver, lung, and kidney demonstrates no serious damage (Figure 7e). All of the results provided evidence for its antitumorigenic action with low hepatotoxicity in vivo.

To confirm the tumor inhibition mechanism regulated by the title compound, tumor tissue and tissue protein were prepared. As shown in Figure 8, through the immunohistochemistry experiment, the tumor tissue were stained with the hTERT (Figure 8a) and p65 (Figure 8b) antibody and the results showed that the intensity of hTERT and p65 markedly 


\section{a}
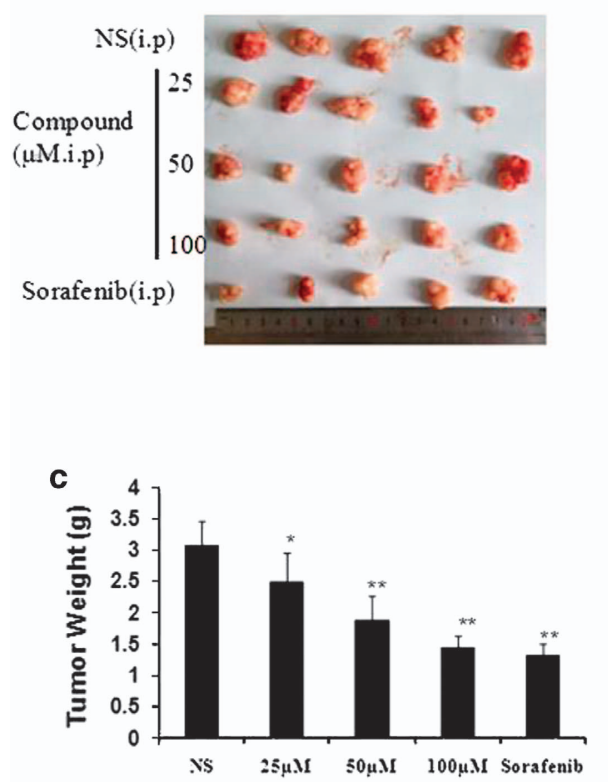

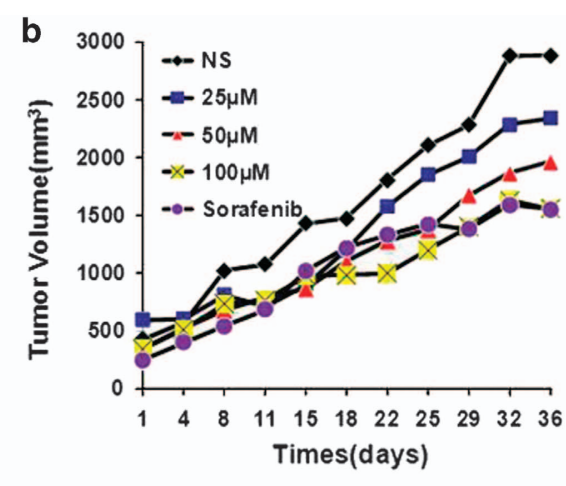

d

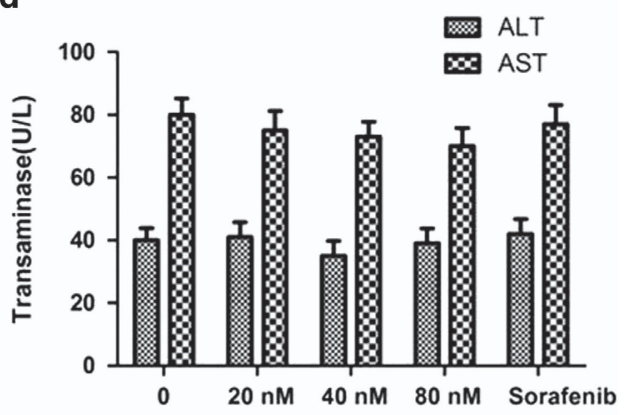

e

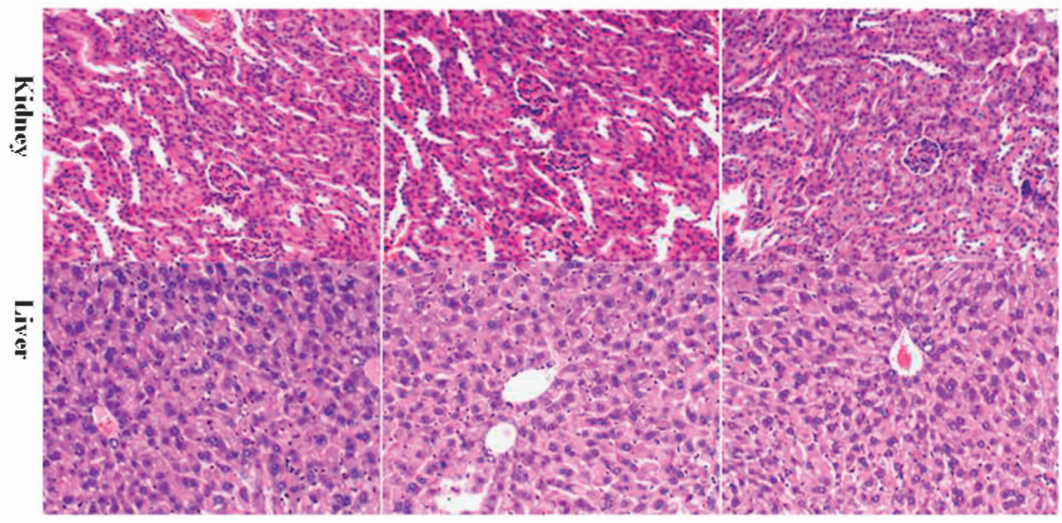

control

$25 \mu \mathrm{M}$

$50 \mu \mathrm{M}$

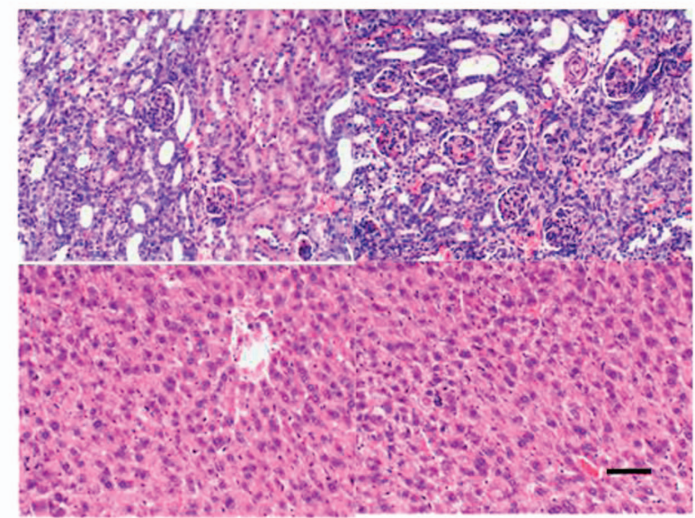

$100 \mu \mathrm{M}$

Sorafenib

Figure 7 Title compound significantly delays SMMC-7721 tumor growth. (a) Representative tumors from each treatment group. (b) Tumor volume of the mice. (c) Tumor weights after the title compound and sorafenib treatment. (d) In vivo hepatotoxicity evaluation of compound in nude mice. The AST and ALT were determined with Assay Kit. The blood serum samples were treated according to the manufacturer's instruction. Moreover, the AST and ALT activities are expressed as U/I. (e) H\&E-stained sections of the liver and kidney from the mice after treatment. For the statistics of each panel in this figure, data are expressed as mean \pm S.D. $(n=3)$; scale bars are $50 \mu$ m; ${ }^{*} P<0.05$ versus control, ${ }^{\star *} P<0.01$ versus control 

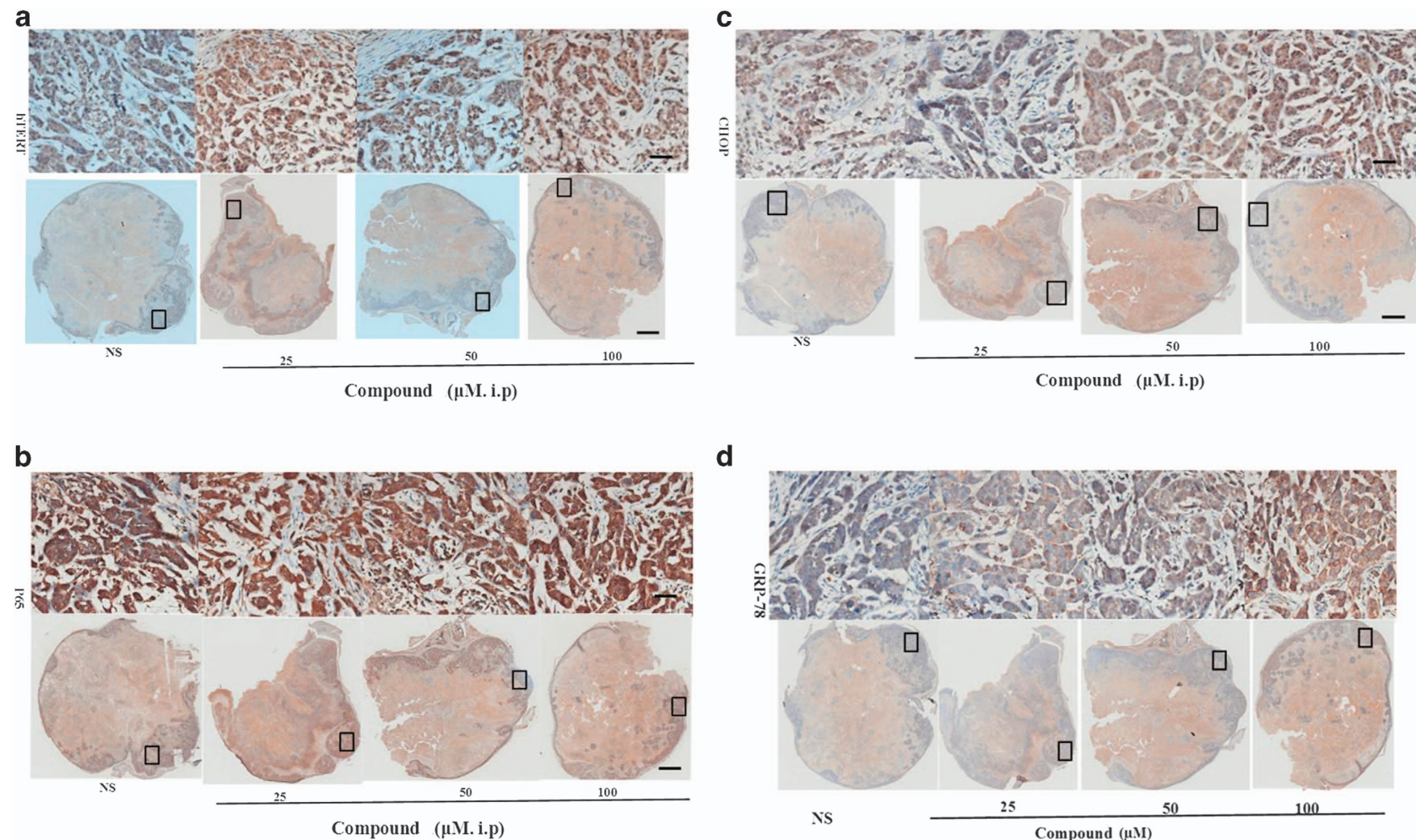

d
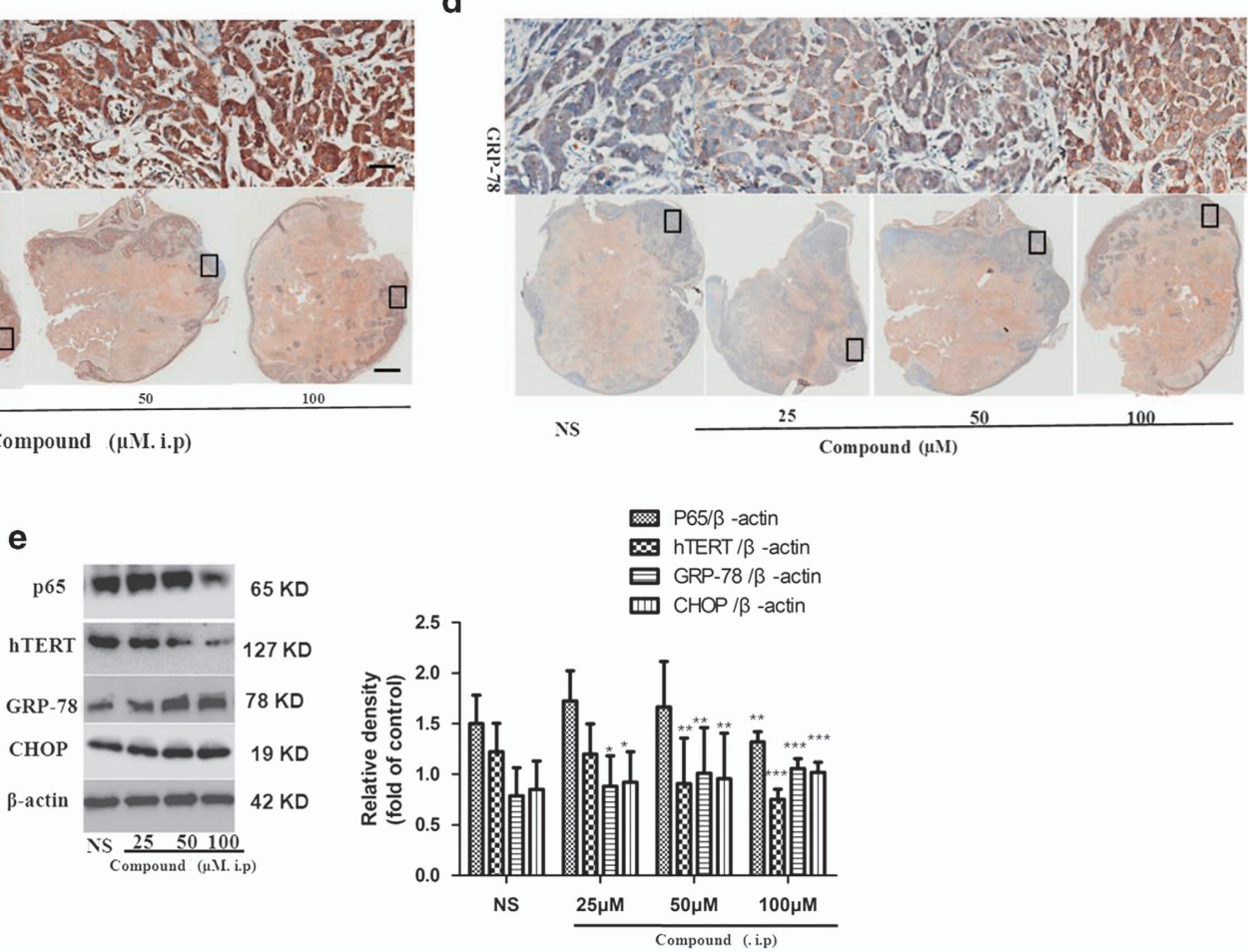

Figure 8 Title compound increased apoptosis and reduced proliferation in vivo. (a-d) The sections were also stained for hTERT, p65, CHOP, and GRP-78. (e) Total proteins were extracted from tumor tissue and were subjected to western blot and densitometric analyses. The densitometric quantitation ratio of hTERT, p65, CHOP, and GRP-78 normalized to the $\beta$-actin level. For the statistics of each panel in this figure, data are expressed as mean \pm S.D. $(n=3)$; scale bars are $25 \mu \mathrm{m}$; ${ }^{*} P<0.05$ versus control, ${ }^{* *} P<0.01$ versus control, ${ }^{* * *} P<0.001$ versus control

decreased in the title compound groups compared with NS groups. At the same time the intensity of CHOP (Figure $8 \mathrm{c}$ ) and GRP-78 (Figure 8d) increased in the title compound groups compared with NS groups. In Figure 8e, through western blotting and densitometric analysis, the effects of title compound on hTERT, p65, CHOP, and GRP-78 were confirmed. These results suggested that the title compound effectively inhibited tumor development in vivo via the same mechanism that was preliminarily discovered in vitro.

\section{Discussion}

Hepatocellular carcinoma (HCC) is a common malignancy and the third leading cause of cancer-related deaths worldwide. In patients with advanced HCC, death is usually caused by tumor cell invasion and metastasis. ${ }^{30}$ Telomerase is a cellular reverse transcriptase that catalyzes the synthesis and extension of telomeric DNA. Telomerase activity is undetectable in normal somatic cells. However, the length of telomere is stabilized and telomerase activity can be detected in about $85 \%$ of cancer cells. Reactivation of telomerase is believed to be involved in cellular immortalization and tumorigenesis. ${ }^{31}$ Therefore, telomerase has been proposed to be a selective target for cancer therapy.

In our preliminary research based on telomerase, ${ }^{18}$ a series of phenstatin-stavudine hybrids was designed, in which some compounds displayed potent antitelomerase activity. In this study, a compound with very high antitumor activity and selectivity to normal cells was discovered. What is more surprising is that hTERT was upregulated as early as $3 \mathrm{~h}$ and 
decreased at $12 \mathrm{~h}$. On the basis of this, the preliminary mechanisms were revealed. Our results show that the title compound could induce ERS. It activates a novel pathway for ERS to induce calcium release and reduce telomerase activity. Changes in hTERT localization were also identified. Prevention of nuclear export of hTERT with p65 significantly enhanced telomerase activity when treated with the compound.

The ER, as one of the largest organelles in eukaryotic cells, is a membrane-bound network of branching tubules and flattened sacs that has a major role in the synthesis, folding, and structural maturation of proteins, especially those destined for secretion or to the plasma membrane. Multiple cellular stresses, such as oxidative stress, altered protein glycosylation, or protein-folding defects, lead to accumulation of unfolded or misfolded proteins in the ER lumen and disturb ER function causing 'ERS'. These ERS signals activate transcriptional and translational pathways that deal with unfolded and misfolded proteins, known as the UPR ${ }^{32,33}$ and EOR. UPR and EOR employ various mechanisms at the transcriptional and the translational levels to deal efficiently and appropriately with encountered stress. ${ }^{20} \mathrm{NF}-\kappa \mathrm{B}$, activated in EOR, may also have conflicting roles as far as cell fate is concerned. Under normal conditions, it is found in the cytoplasm as an inactive heterodimer complexed with $\mathrm{I}-\kappa \mathrm{B}$. Direct activation of NF-KB is achieved because of the phosphorylation and subsequent degradation of its inhibitor, I-KB. In addition, previous study has suggested that NF-kB may protect cells against ERS-induced death by repression of $\mathrm{CHOP}^{34}$ Furthermore, it has been shown that in some systems NF- $K \mathrm{~B}$ is required for $\mathrm{p53}$-dependent cell death and that $\mathrm{Bcl}-2$ may exert its protective function by suppressing
NF- $\kappa$ B DNA-binding ability. At the same time, it was well known that the transcription factor NF- $\kappa$ B has been implicated with the regulation of $\mathrm{hTERT}$ transcription. Our results showed that p65, hTERT, and IKB were upregulated at $3 \mathrm{~h}$ after EOR induction and decreased at $12 \mathrm{~h}$ post induction when the UPR was induced in a time-dependent manner and treated with the title compound. In addition, p65 and hTERT were also downregulated in a dose-dependent manner.

In response to chemotherapeutic drugs, cells adapted to accumulation of unfolded and misfolded proteins by ERS. ERS protects cell by shutting down the general protein synthesis and increasing the expression of molecular chaperones such as ER-resident hsp70 homolog and glucoseregulated protein 78 (GRP-78). ${ }^{35}$ When ERS is prolonged, the pro-death ERS pathways are mediated by CHOP. ERSinduced apoptosis is a key pathologic event of antitumor effects in many cancers. ${ }^{36,37}$ Our results showed that $p$-PERK, p-elF2 $a$, and ATF4 were upregulated in a time-dependent manner after treatment of compound, indicating that ERS was activated. What's more, the ERS associated apoptotic

Table 1 Sequences of qRT-PCR oligonucleotide primers specific hTERT, GRP-78, and $\beta$-actin

\begin{tabular}{lll}
\hline Gene & Direction & Sequence \\
\hline$h T E R T$ & Forward & 5'-CTTCCACTCCCCACATAGGA-3' \\
& Reverse & 5'-CCTTCTCAGGGTCTCCACCT-3' \\
GRP-78 & Forward & 5'-GAGGGGAGGGAGTATTTGGT-3' \\
& Reverse & 5'-CTGGGAGACTGAGGTGGAAG-3' \\
$\beta$-actin & Forward & 5'-AACTACCTTCAACTCCATCA-3' \\
& Reverse & 5'-GAGCAATGATCTTGATCTTCA-3'
\end{tabular}

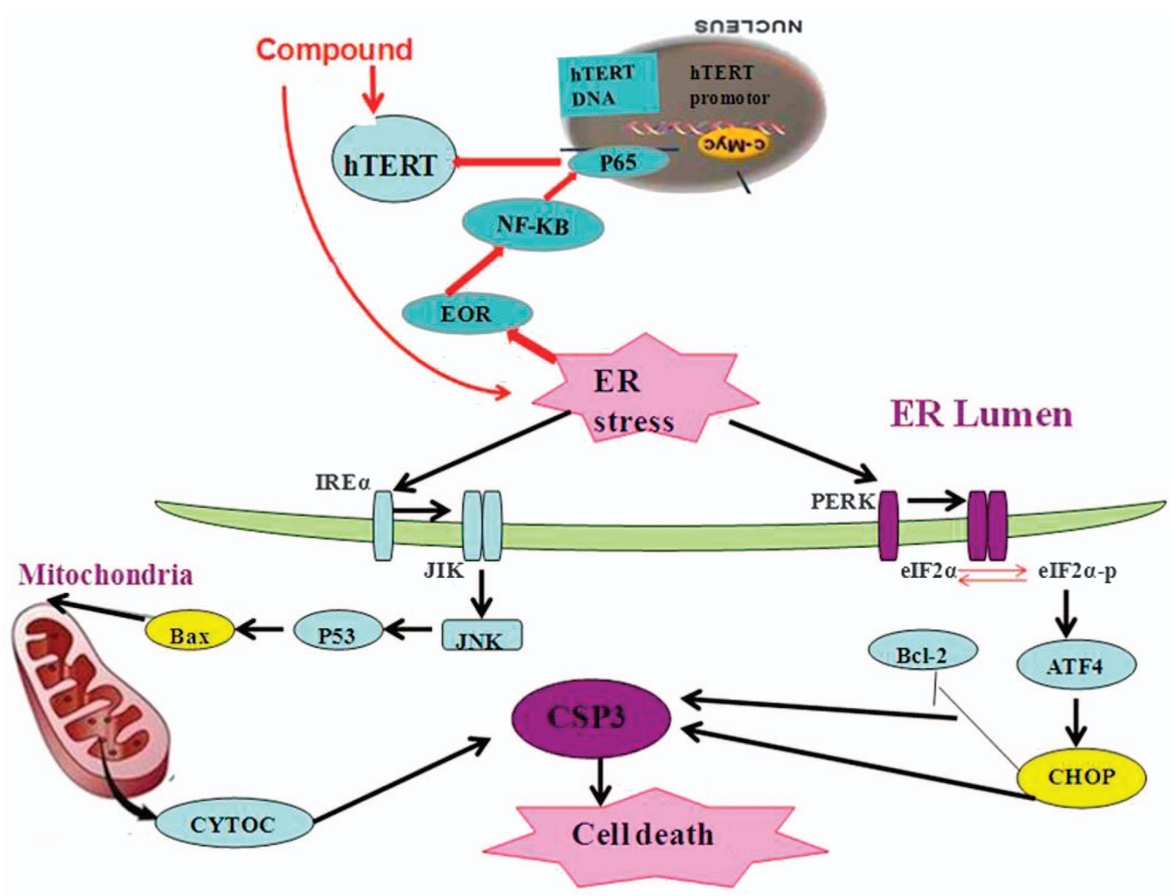

Figure 9 Scheme of the underlying mechanism of the title compound through regulating hTERT induces cell apoptosis and ER stress 
pathway protein $\mathrm{CHOP}$ after compound treatment with SMMC-7721 cells. In addition, p-PERK, p-elF2a, ATF4, and $\mathrm{CHOP}$ were also upregulated in a dose-dependent manner.

Recent studies have revealed the significance of ER-mitochondrial crosstalk in pathophysiological situations. The ER and mitochondria join together at several contact sites to form specific domains, termed mitochondria-ERassociated membranes or mitochondria-associated ER membranes. ${ }^{32}$ Some studies have demonstrated that the UPR can activate the mitochondrial apoptotic pathway through JNK/IRE1, which is critically regulated by several members of the Bcl-2 family. ERS induces conformational changes in Bax, changing them from inactive to active forms and setting the apoptotic pathway in motion. ${ }^{24,25}$ On the basis of the information available so far, the scheme for ERSinduced mitochondrial dysfunction and protection by the title compound can be presented (Figure 9).

\section{Conclusion}

In summary, a novel title compound with high selectivity against tumor cells versus human somatic cells was discovered. Flow cytometry and fluorescence microscope assays indicated that it could induce cell apoptosis. Western blot assays showed that it could significantly induce the expressions of GRP-78, hTERT, and p65. Furthermore, it could also induce the ERS. Our experiments first demonstrated that the title compound could, through EOR, activate p65, and then hTERT. When the compound induced ERS, which is prolonged and severe, the UPR ${ }^{\mathrm{ER}}$ activates a cell death pathway, usually via intrinsic apoptosis, which involves the mitochondria. Therefore, the title compound inhibited the proliferation of SMMC-7721 and altered the cell fate from a pro-survival pathway to a pro-death mechanism, eventually inducing cell death. Furthermore, these results are of help in the rational design of more efficient telomerase hTERT modulators.

\section{Materials and Methods}

Chemistry. The reactions were monitored using thin-layer chromatography GF254 plates. Melting points were determined on a XT4MP apparatus (Taike Corp., Beijing, China), and are uncorrected. ${ }^{1} \mathrm{H}$ NMR spectra were recorded on a Brucker AM-300 $(300 \mathrm{MHz})$ spectrometer with $\mathrm{CDCl}_{3}$ as the solvent. Mass spectra were performed on an Agilent (CA, USA) 1260-6221 TOF mass spectrometer. Al reagents were purchased from standard commercial suppliers and treated with standard methods.

Synthesis of the title compound. To 2-methoxyphenol $(10 \mathrm{mmol})$ was added chloroacetyl chloride $\left(15 \mathrm{mmol}\right.$ ) under $\mathrm{N}_{2}$ atmosphere; the reaction mixture was heated to $120^{\circ} \mathrm{C}$ for $7 \mathrm{~h}$ with stirring. The mixture was cooled and carefully added to cold water, and then was extracted with $\mathrm{CH}_{2} \mathrm{Cl}_{2}(3 \times 30 \mathrm{ml})$. The combined organic phase was washed with water, saturated $\mathrm{NaHCO}_{3}$, and brine, and was dried with anhydrous $\mathrm{Na}_{2} \mathrm{SO}_{4}$. The solvent was evaporated to yield a yellow oil, and then recrystallized with ethanol to yield white needle-like crystal compound 2 . To an Eaton's reagent $(50 \mathrm{ml})$, benzoic acid $(65 \mathrm{mmol})$ and compound $2(45 \mathrm{mmol})$ were added to ice bath solution. The reaction mixture was allowed to stand at $40^{\circ} \mathrm{C}$ for $9 \mathrm{~h}$ and poured into ice water $(150 \mathrm{ml})$. The mixture was extracted with $\mathrm{CH}_{2} \mathrm{Cl}_{2}$ $(3 \times 30 \mathrm{ml})$. The residue was refluxed in ethanol and filtered through a Büchner funnel to yield off-white powder 4 . To a solution of compound $4(10 \mathrm{mmol})$ in $\mathrm{MeOH}$ $(30 \mathrm{ml})$ was added $\mathrm{NaOAc}(35 \mathrm{mmol})$. The reaction mixture was refluxed for $50 \mathrm{~min}$. The obtained residue was treated with $\mathrm{H}_{2} \mathrm{O}(10 \mathrm{ml})$, filtered, and dried to yield compound $\mathbf{5}$ as white powders.
Reagents and antibodies. The compound was obtained as described previously. They were dissolved in dimethyl sulfoxide (DMSO, Biosharp, Hefei, China) and stored at $-20{ }^{\circ} \mathrm{C}$. Sorafenib, 4,6-diamidino-2-phenylindole (DAPI), 3(4,5-Dimethylthiazol-2-yl)-2,5-diphenyltetrazolium bromide (MTT), DMSO, anti-rabbit $\operatorname{lgG}$, and anti-mouse IgG were purchased from Sigma-Aldrich (St. Louis, MO, USA). Dulbecco's modified essential medium (DMEM), phosphate-buffered saline (PBS), trypsin-EDTA, and fetal bovine serum (FBS) were bought from GIBCO BRL. The Annexin V-FITC/PI apoptosis detection kit was purchased from Nanjin KeyGen Biotech (Nanjing, China). The following primary antibodies were used: GRP-78, hTERT, p65, IKB, Bcl-2, Bax, cyt-c, CHOP, PERK/p-PERK, p-elF2 $\alpha$, ATF4, IRE1, $\mathrm{p}-\mathrm{IRE} 1 \alpha$, and $\beta$-actin were purchased from Abcam Technology (Abcam, Cambridge, UK).

Cell culture. The human hepatoma cell line SMMC-7721 was obtained from the American Type Culture Collection (Manassas, VA, USA). Cells were maintained in DMEM with $10 \%$ (v/v) FBS (Hyclone, Logan, UT, USA) at $37^{\circ} \mathrm{C}$ in a $5 \% \mathrm{CO}_{2}$ humidified air incubator (Thermo Scientific, Waltham, MA, USA).

Animals and experimental design. All experimental procedures were approved by the institutional and local committee on the care and use of the Animal Center of the Shanghai Institute of Chinese Medicine (Shanghai, China), and all animals received humane care according to the National Institutes of Health (USA) guidelines. Female BALB/c nu/nu nude mice, 5-week old, weighing 18-22 g, were procured from the Animal Center of the Shanghai Institute of Chinese Medicine (Shanghai, China). Twenty-five BALB/c nu/nu nude mice were randomly divided into four groups of five animals each with comparable mean body weight. Mice of Group 1 served as a vehicle control and intraperitoneally (i.p.) injected with NS every day for 5 weeks. Mice of Group 2 served as a positive control and i.p. injected with Sorafenib every day for 5 weeks. Mice of Groups 3-5 were i.p. injected with the compound every day for 5 weeks. The compound was suspended in sterile PBS and given once daily by intraperitoneal injection. At the end of the experiment, rats were killed. The liver and kidney were removed for histopathological studies to observe the toxicity of compound. At the same time, the tumors were removed for immunohistochemical studies.

Cell viability assay. Cell viability was assessed by MTT assay. For MTT assay, SMMC-7721 cells were seeded in 96-well plates at $1 \times 10^{4} \mathrm{cells} / \mathrm{ml} / \mathrm{well}$ and were allowed to grow to $70 \sim 80 \%$ confluency, and the cells were treated with different concentrations of compound 1 for $48 \mathrm{~h}$. Treated cells were incubated with MTT ( $2 \mathrm{mg} / \mathrm{ml}$ in $5 \%$ ethanol) for $4 \mathrm{~h}$ at $37^{\circ} \mathrm{C}$, the medium was removed and dye crystal formazan was solubilized in $200 \mu \mathrm{l}$ DMSO. The absorbance was measured at $570 \mathrm{~nm}$. The relative amount of inhibition of cell growth was calculated as follows:

Cellviability $(\%)=($ Asample - Ablank $) /($ Acontrol - Ablank $) \times 100 \%$

Colony formation assay. Clonogenic assay was performed to evaluate the ability of a cell to grow into a colony and the antiproliferative activity of tested compound was checked. SMMC-7721 cells were seeded in a six-well plate at a density of $4 \times 10^{3} \mathrm{cells} / \mathrm{ml} / \mathrm{well}$. After $24 \mathrm{~h}$, the culture medium was changed and a new medium was added, and cells were treated with different low concentrations of the compound. Following treatment for $24 \mathrm{~h}$, the medium was changed and fresh medium was added alternately up to 7 days. Later on, the obtained colonies were fixed with $4 \%$ paraformaldehyde and were stained with $0.5 \%$ crystal violet solution. The mixture was removed after $30 \mathrm{~min}$; plates were washed with water and allowed to dry at room temperature. The colonies from the plates were counted and averaged from the observed fields randomly $(n=3)$ and were photographed.

Detection of apoptosis by Annexin V-FITC and PI. Annexin V-FITC and $\mathrm{PI}$ dual staining is usually used to detect the early and late apoptotic cells. For measuring apoptosis, SMMC-7721 cells were seeded in six-well plates $\left(2 \times 10^{5}\right.$ cells $/ \mathrm{ml} /$ well) and were treated with compound for $48 \mathrm{~h}$. After $48 \mathrm{~h}$, the cells were collected, washed twice with PBS, and resuspended in binding buffer. Thereafter, the cells were stained with Annexin V-FITC and PI for $15 \mathrm{~min}$ in the dark and were analyzed by flow cytometry.

Measurement of MMP $(\Delta \boldsymbol{\Psi} \mathrm{m})$ loss. Loss in MMP as a result of mitochondrial perturbation was studied using flow cytometry and confocal microscopy after staining with $5,5^{\prime}, 6,6^{\prime}$-tetrachloro-1,1',3,3'-tetraethyl benzimidalyl 
carbocyanine iodide (JC-1). SMMC-7721 cells $\left(2 \times 10^{5} \mathrm{cell} / \mathrm{s} / \mathrm{m} /\right.$ well) were seeded in a six-well plate and treated with different concentrations of the compound for $48 \mathrm{~h}$. Untreated cells and cells treated with test material(s) were trypsinized and washed twice with PBS. The cell pellets were then suspended in $2 \mathrm{ml}$ fresh medium containing JC-1 and were incubated at $37^{\circ} \mathrm{C}$ for 20 min with gentle shaking. Cells were collected by centrifugation, washed twice with PBS, and then analyzed by flow cytometry.

Chromatin condensation stained with DAPI. SMMC-7721 cells $\left(1 \times 10^{5} \mathrm{cells} /\right.$ well $)$ were placed in 12-well plates and the cells were treated with the Compound at final concentrations $(0,20,40$, and $80 \mathrm{~nm})$ for $48 \mathrm{~h}$. Cells were fixed in 3\% paraformaldehyde in PBS for 20 min at room temperature, followed by washing with PBS. Cells were then stained with DAPI solution $(2 \mu \mathrm{g} / \mathrm{ml})$ at room temperature in the dark. The chromatin condensation (nuclear morphology) was examined and photographed using a fluorescence microscope.

Telomerase activity assays. The title compound was tested for the telomerase activity by using the TRAP-PCR-ELISA assay. ${ }^{18}$ In detail, the SMMC-7721 cells were first maintained in RPMI 1640 buffer (Hyclone, Miami, FL, USA), supplemented with $10 \%$ FBS (GIBCO, New York, NY, USA), streptomycin $(0.1 \mathrm{mg} / \mathrm{ml})$, and penicillin $(100 \mathrm{IU} / \mathrm{ml})$ at $37^{\circ} \mathrm{C}$ in a humidified atmosphere containing $5 \% \mathrm{CO}_{2}$. After trypsinization, $5 \times 10^{4}$ cultured cells in logarithmic growth were seeded into T25 flasks (Corning Life Science, New York, NY, USA) and cultured to allow adherence. The cells were then incubated with Staurosporine (Santa Cruz, Santa Cruz, CA, USA) and the compound with a series of concentrations as $60,20,6.67,2.22,0.75,0.25$, and $0.082 \mathrm{I} \mathrm{g} / \mathrm{ml}$. After $24 \mathrm{~h}$ treatment, the cells were harvested by cell scraper orderly followed by being washed once with PBS. The cells were lysed in $150 \mu$ l RIPA cell lysis buffer (Santa Cruz) and incubated on ice for $30 \mathrm{~min}$. The cellular supernatants were obtained via centrifugation at $12000 \times \mathrm{g}$ for $20 \mathrm{~min}$ at $4^{\circ} \mathrm{C}$ and stored at $-80^{\circ} \mathrm{C}$. The TRAPPCR-ELISA assay was performed using a telomerase detection kit (Roche, Basel, Switzerland) according to the manufacturer's protocol. In brief, $2 \mu$ l of cell extracts were mixed with $48 \mu$ l TRAP reaction mixtures. TRAP primers and Taq polymerase were incubated at $25^{\circ} \mathrm{C}$ for $30 \mathrm{~min}$. PCR was then initiated at $94^{\circ} \mathrm{C}$, for $120 \mathrm{~s}$ for predenaturation and was performed using 35 cycles, each consisting of $94^{\circ} \mathrm{C}$ for $30 \mathrm{~s}, 50^{\circ} \mathrm{C}$ for $30 \mathrm{~s}$, and $72{ }^{\circ} \mathrm{C}$ for $90 \mathrm{~s}$. Then, $20 \mu \mathrm{l}$ of PCR products were hybridized to a digoxigenin (DIG)-labeled telomeric repeat-specific detection probe. In addition, the PCR products were immobilized via the biotin-labeled primer to a streptavidin-coated microtiter plate subsequently. The immobilized DNA fragments were detected with a peroxidase-conjugated anti-DIG antibody and were visualized following addition of the stop reagent. The microtiter plate was assessed on TECAN Infinite M200 microplate reader (Mannedorf, Switzerland) at a wavelength of $490 \mathrm{~nm}$, and the final value was presented as mean \pm S.D.

Quantitative reverse transcription PCR. Total RNA was isolated using TRIzol reagent (Invitrogen Life Technologies, Carlsbad, CA, USA). Aliquots (1 $\mu \mathrm{g})$ of RNA were reverse-transcribed to CDNA $(20 \mu \mathrm{l})$ using oligo (dT) and M-MuLV reverse transcriptase (Fermentas Inc., Glen Burnie, MD, USA) following the instructions of the manufacturer. One-fifth of the cDNA was used as a template for PCR using the SYBR-Green PCR kit (Takara, Kyoto, Japan) in an ABI StepOne Real-Time PCR System (Applied Biosystems, Foster City, CA, USA). The housekeeping gene, glyceraldehyde-3-phosphate dehydrogenase, was selected as an internal control for each experiment. The primers used in this study are presented in Table 1. The cycling conditions were as follows: predenaturation at $95{ }^{\circ} \mathrm{C}$ for $10 \mathrm{~min}$, followed by 40 cycles at $95^{\circ} \mathrm{C}$ for $10 \mathrm{~s}$, at $57 \sim 60^{\circ} \mathrm{C}$ for $20 \mathrm{~s}$, and at $72{ }^{\circ} \mathrm{C}$ for $15 \mathrm{~s}$. The specificity of the amplification products was confirmed by a melting curve analysis. All reactions were run in triplicate. As a measure of relative change in expression between the parental and resistant samples, $\Delta \Delta \mathrm{Ct}$ values were calculated and converted to approximate fold change values $(2-\Delta \Delta \mathrm{Ct})$. The sequences of qRT-PCR oligonucleotide primer-specific hTERT, GRP-78, and $\beta$-actin can be seen in Table 1.

Western blot analysis. The cells were plated in six-well culture dishes (Corning Life Sciences) at a density of $4 \times 10^{5} \mathrm{celll} / \mathrm{ml} / \mathrm{well}$. Following $24 \mathrm{~h}$ of incubation, the cells were washed with $1 \mathrm{MI}$ PBS/well and were harvested using trypsin. Harvested cells were centrifuged and resuspended in lysis buffer. Following incubation on ice for $30 \mathrm{~min}$, the homogenate was centrifuged at 12000 r.p.m. for $30 \mathrm{~min}$ at $4{ }^{\circ} \mathrm{C}$. Protein concentrations were determined using a bicinchoninic acid (BCA) assay (Beyotime Institute of Biotechnology, Beijing, China). Subsequently,
$40 \mu \mathrm{g}$ of protein were separated using 10 15\% sodium dodecyl sulfatepolyacrylamide gel electrophoresis and transferred onto polyvinylidene difluoride membranes. The blotted membranes were blocked with $5 \%$ skim milk for $2 \mathrm{~h}$ and probed with primary antibodies overnight at $4^{\circ} \mathrm{C}$. The membranes were washed and probed with secondary antibodies for $1 \mathrm{~h}$. The membranes were imaged with gel imaging equipment (Bio-Rad, Hercules, CA, USA). $\beta$-actin was used as the loading control.

Immunofluorescence analysis. Cells were cultured on sterile glass coverslips and were treated with the compound for $24 \mathrm{~h}$. Cells were then fixed with $4 \%$ formaldehyde at room temperature for $15 \mathrm{~min}$. The cells were rinsed twice with $1 \times$ PBS, permeabilized using $0.5 \%$ Triton X-100/PBS for 15 min, and blocked in blocking solution $(5 \%(\mathrm{w} / \mathrm{v}) \mathrm{BSA}$ in $1 \times$ TBST). They were then incubated with primary antibodies overnight at $4{ }^{\circ} \mathrm{C}$ and were rinsed three times in $1 \times$ PBS for $15 \mathrm{~min}$ and then incubated with secondary antibodies (Alexa Fluor 488 dye, Life Technologies, Gaithersburg, MD, USA) for $1 \mathrm{~h}$ and with DAPI for $15 \mathrm{~min}$ at room temperature, they were then rinsed four times in $1 \times$ TBST for $20 \mathrm{~min}$. ProLong Gold Antifade Mountant was added to the cells. Fluorescent images were taken using an EVOS microscope (Thermo Fisher Scientific).

In vivo studies. Female $B A L B / c$ nu/nu nude mice (5-week old) were obtained from the Animal Center of the Shanghai Institute of Chinese Medicine and were maintained under specific pathogen-free conditions. The management of animals was conducted in accordance with the Guide for the Care and Use of Laboratory Animals. All experiments were performed using procedures that minimized the stress and pain experienced by the animals. SMMC-7721 cells $\left(1 \times 10^{7}\right.$ cells in $200 \mathrm{ml}$ PBS medium) were subcutaneously injected into the right flank of the mice. The resulting tumor growth was monitored with calipers using the following formula: volume $=a \times b^{2} / 2$, where $a$ denotes the length and $b$ denotes the width. When the mean tumor volume reached $0.5 \mathrm{~cm}^{3}$, the mice were randomly separated into five groups ( $n=5 /$ group), and the treatments were initiated as follows: (a) the mice in the control group received an intraperitoneal injection of NS, injections of $0.2 \mathrm{ml} /$ $10 \mathrm{~g}$ every day; (b) the mice in the compound group received an intraperitoneal injection of compound ( 25,50 , and $100 \mu \mathrm{M})$, injections of $0.2 \mathrm{ml} / 10 \mathrm{~g}$ every day. (c) the mice in the Sorafenib group received i.p. injections of $30 \mathrm{mg} / \mathrm{kg}$ daily. After 37 days of treatment, all of the nude mice were killed, and the tumors were formalinfixed and stained with GRP-78, hTERT, p65, and CHOP.

Immunohistochemistry. Tissue slides were incubated at $65^{\circ} \mathrm{C}$ for $30 \mathrm{~min}$ and then subjected to deparaffinization in xylene for $10 \mathrm{~min}$ in a microwave oven for antigen retrieval. After washing with $1 \cdot \mathrm{NaClPi}$, the slides were immersed in $3 \%$ hydrogen peroxide for $10 \mathrm{~min}$ to suppress endogenous peroxidase activity. After triple rinses with $1 \cdot \mathrm{NaCl} / \mathrm{Pi}$, the sections were incubated with primary antibodies for $1 \mathrm{~h}$ at room temperature. After triple rinses with $1 \cdot \mathrm{NaCl} / \mathrm{Pi}$, the slides were incubated with biotinylated secondary antibody (Dako, Glostrup, Denmark) for $25 \mathrm{~min}$. Following triple rinses with $1 \cdot \mathrm{NaCl} / \mathrm{Pi}$, horseradish peroxidase-conjugated streptavidin was added for $25 \mathrm{~min}$ at room temperature. The peroxidase activity was detected with alkaline earth cuprate (AEC+) substrate chromogen (Dako) at room temperature. The slides were then counterstained with hematoxylin. Images were taken using an EVOS microscope.

Histological analysis. Hematoxylin and eosin, Sirius Red, and Masson stainings were performed on $4-\mu \mathrm{m}$-thick formalin-fixed paraffin-embedded tissue sections. Sirius Red- and Masson-stained areas from 10 fields (magnification $\times 200$ ) were quantified with Image $\mathrm{J}$.

Statistical analysis. Values are expressed as the means \pm S.D. of three experiments. SPSS v.16.0 software (SPSS Inc., Chicago, IL, USA) was used for data analysis. Comparisons between two groups were analyzed using the two-tailed Student's $t$-test. A $P$-value $<0.05$ is considered statistically significant.

\section{Conflict of Interest}

The authors declare no conflict of interest.

Acknowledgements. We thank the National Natural Science Foundation of China (Nos. 21272008 and 21572003) and the Natural Science Foundation of Anhui Province (No. $1508085 \mathrm{QH} 195)$. 


\section{Publisher's Note}

Springer Nature remains neutral with regard to jurisdictional claims in published maps and institutional affiliations.

1. Wright WE, Shay JW. Cellular senescence as a tumor-protection mechanism: the essential role of counting. Curr Opin Genet Dev 2001; 11: 98-103.

2. Paul A, Maji B, Misra SK, Jain AK, Muniyappa K, Bhattacharya S. Stabilization and structural alteration of the G-quadruplex DNA made from the human telomeric repeat mediated by Troger's base based novel benzimidazole derivatives. J Med Chem 2012; 55: 7460-7471.

3. Stewart SA, Bertuch AA. The role of telomeres and telomerase in cancer research. Cancer Res 2010; 70: 7365-7371.

4. Shay JW, Wright WE. Telomerase: a target for cancer therapeutics. Cancer Cell 2002; 2: $257-265$.

5. Shay JW, Wright WE. Telomerase therapeutics for cancer: challenges and new directions. Nat Rev Drug Discov 2006; 5: 577-584.

6. Sekaran V, Soares J, Jarstfer MB. Telomere maintenance as a target for drug discovery. J Med Chem 2014; 57: 521-538.

7. Herbert B, Pitts AE, Baker SI, Hamilton SE, Wright WE, Shay JW et al. Inhibition of human telomerase in immortal human cells leads to progressive telomere shortening and cell death. Proc Natl Acad Sci USA 1999; 96: 14276-14281.

8. Wu XQ, Huang C, He X, Tian YY, Zhou DX, Liu XH et al. Feedback regulation of telomerase reverse transcriptase: new insight into the evolving field of telomerase in cancer. Cell Signal 2013; 25: 2462-2468.

9. Nakamura TM, Morin GB, Chapman KB, Weinrich SL, Andrews WH, Lingner J et al. Telomerase catalytic subunit homologs from fission yeast and human. Science 1997; 277 955-959.

10. Meyerson M, Counter CM, Eaton EN, Ellisen LW, Steiner P, Caddle SD et al. hEST2, the putative human telomerase catalytic subunit gene, is up-regulated in tumor cells and during immortalization. Cell 1997; 90: 785-795.

11. Wang Y, Cheng FX, Yuan XL, Tang WJ, Shi JB, Liu XH et al. Dihydropyrazole derivatives as telomerase inhibitors: structure-based design, synthesis, SAR and anticancer evaluation in vitro and in vivo. Eur J Med Chem 2016; 112: 231-251.

12. Chen YY, Wu XQ, Tang WJ, Shi JB, Li J, Liu XH. Novel dihydropyrazole-chromen: design and modulates hTERT inhibition proliferation of MGC-803. Eur J Med Chem 2016; 110: 65-75.

13. Barma DK, Elayadi A, Falck JR, Corey DR. Inhibition of telomerase by BIBR 1532 and related analogues. Bioorg Med Chem Lett 2003; 13: 1333-1336.

14. El-Daly H, Kull M, Zimmermann S, Pantic M, Waller CF, Martens UM. Selective cytotoxicity and telomere damage in leukemia cells using the telomerase inhibitor BIBR1532. Blood 2005; 105: 1742-1749.

15. Pascolo E, Wenz C, Lingner J, Hauel N, Priepke H, Kauffmann I et al. Mechanism of human telomerase inhibition by BIBR1532, a synthetic, non-nucleosidic drug candidate. J Biol Chem 2002; 277: 15566-15572.

16. Huang HS, Chiou JF, Fong Y, Hou CC, Lu YC, Wang JY et al. Activation of human telomerase reverse transcriptase expression by some new symmetrical bis-substituted derivatives of the anthraquinone. J Med Chem 2003; 46: 3300-3307.

17. Hayakawa N, Nozawa K, Ogawa A, Kato N, Yoshida K, Akamatsu K et al. Isothiazolone derivatives selectively inhibit telomerase from human and rat cancer cells in vitro. Biochemistry 1999; 38: 11501-11507.

18. Shi JB, Chen LZ, Wang Y, Cheng X, Tang WJ, Liu XH et al. Benzophenone-nucleoside derivatives as telomerase inhibitors: design, synthesis and anticancer evaluation in vitro and in vivo. Eur J Med Chem 2016; 124: 729-739.

19. Zhou J, Mao B, Zhou Q, Ding D, Wang M, Guo $P$ et al. Endoplasmic reticulum stress activates telomerase. Aging cell 2014; 13: 197-200.

20. Cudna RE, Dickson AJ. Endoplasmic reticulum signaling as a determinant of recombinant protein expression. Biotechnol Bioeng 2003; 81: 56-65.

21. Masutomi K, Yu EY, Khurts S, Ben-Porath I, Currier JL, Metz GB et al. Telomerase maintains telomere structure in normal human cells. Cell 2003; 114: 241-253.

22. Hung JH, Su IJ, Lei HY, Wang HC, Lin WC, Chang WT et al. Endoplasmic reticulum stress stimulates the expression of cyclooxygenase-2 through activation of NF- $\kappa B$ and pp38 mitogen-activated protein kinase. J Biol Chem 2004; 279: 46384-46392.
23. Sinha-Datta U, Horikawa I, Michishita E, Datta A, Sigler-Nicot JC, Brown M et al. Transcriptional activation of hTERT through the NF-kappaB pathway in HTLV-Itransformed cells. Blood 2004; 104: 2523-2531.

24. Ying QL, Nichols J, Chambers I, Smith A. BMP induction of Id proteins suppresses differentiation and sustains embryonic stem cell self-renewal in collaboration with STAT3. Cell 2003; 115: 281-292.

25. Sehrawat A, Kim SH, Hahm ER, Arlotti JA, Eiseman J, Shiva SS et al. Cancer-selective death of human breast cancer cells by leelamine is mediated by bax and bak activation. $\mathrm{Mol}$ Carcinog 2017; 56: 337-348.

26. Quan Z, Gu J, Dong P, Lu J, Wu X, Wu W et al. Reactive oxygen species-mediated endoplasmic reticulum stress and mitochondrial dysfunction contribute to cirsimaritininduced apoptosis in human gallbladder carcinoma GBC-SD cells. Cancer Lett 2010; 295: 252-259.

27. Clarke HJ, Chambers JE, Liniker E, Marciniak SJ. Endoplasmic reticulum stress in malignancy. Cancer Cell 2014; 25: 563-573.

28. Sobhan PK, Seervi M, Deb L, Varghese S, Soman A, Joseph J et al. Calpain and reactive oxygen species targets Bax for mitochondrial permeabilisation and caspase activation in zerumbone induced apoptosis. PLOS ONE 2013; 8: e59350.

29. Llanos L, Moreu R, Ortin T, Peiro AM, Pascual S, Bellot $P$ et al. The existence of a relationship between increased serum alanine aminotransferase levels detected in premarketing clinical trials and postmarketing published hepatotoxicity case reports. Aliment Pharmacol Ther 2010; 31: 1337-1345.

30. Liu J, Zhang G, Lv Y, Zhang X, Ying C, Yang S et al. SGK2 promotes hepatocellular carcinoma progression and mediates GSK-3beta/beta-catenin signaling in HCC cells. Tumour Biol 2017; 39: 1010428317700408.

31. Liao CH, Hsiao YM, Sheu GT, Chang JT, Wang PH, Wu MF et al. Nuclear translocation of telomerase reverse transcriptase and calcium signaling in repression of telomerase activity in human lung cancer cells by fungal immunomodulatory protein from Ganoderma tsugae. Biochem Pharmacol 2007; 74: 1541-1554.

32. Sreekumar PG, Hinton DR, Kannan R. Endoplasmic reticulum-mitochondrial crosstalk: a novel role for the mitochondrial peptide humanin. Neural Regen Res 2017; 12: 35-38.

33. Oakes SA, Papa FR. The role of endoplasmic reticulum stress in human pathology. Annu Rev Pathol 2015; 10: 173-194.

34. Nozaki S, Sledge GW Jr, Nakshatri H. Repression of GADD153/CHOP by NF-кB: a possible cellular defense against endoplasmic reticulum stress-induced cell death. Oncogene 2001; 20: 2178-2185.

35. Walter $P$, Ron $D$. The unfolded protein response: from stress pathway to homeostatic regulation. Science 2011; 334: 1081-1086.

36. Kim AD, Madduma Hewage SR, Piao MJ, Kang KA, Cho SJ, Hyun JW. Esculetin induces apoptosis in human colon cancer cells by inducing endoplasmic reticulum stress. Cell Biochem Funct 2015; 33: 487-494.

37. Rao R, Nalluri S, Fiskus W, Savoie A, Buckley KM, Ha K et al. Role of CAAT/enhancer binding protein homologous protein in panobinostat-mediated potentiation of bortezomibinduced lethal endoplasmic reticulum stress in mantle cell lymphoma cells. Clin Cancer Res 2010; 16: 4742-4754.

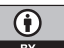

Cell Death and Disease is an open-access journal published by Nature Publishing Group. This work is licensed under a Creative Commons Attribution 4.0 International License. The images or other third party material in this article are included in the article's Creative Commons license, unless indicated otherwise in the credit line; if the material is not included under the Creative Commons license, users will need to obtain permission from the license holder to reproduce the material. To view a copy of this license, visit http://creativecommons.org/licenses/by/4.0/

(C) The Author(s) 2017

Supplementary Information accompanies this paper on Cell Death and Disease website (http://www.nature.com/cddis) 